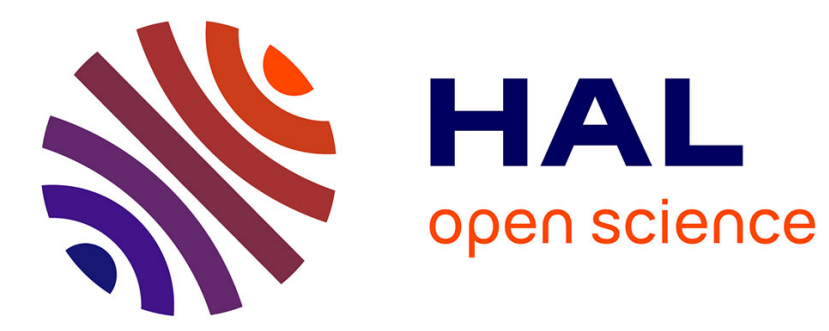

\title{
The effects of education on spouse's satisfaction in Europe
}

\author{
Inmaculada Garcia, Jose Alberto Molina, María Navarro
}

\section{To cite this version:}

Inmaculada Garcia, Jose Alberto Molina, María Navarro. The effects of education on spouse's satisfaction in Europe. Applied Economics, 2008, 42 (28), pp.3607. 10.1080/00036840802314572 . hal00582256

\section{HAL Id: hal-00582256 \\ https://hal.science/hal-00582256}

Submitted on 1 Apr 2011

HAL is a multi-disciplinary open access archive for the deposit and dissemination of scientific research documents, whether they are published or not. The documents may come from teaching and research institutions in France or abroad, or from public or private research centers.
L'archive ouverte pluridisciplinaire HAL, est destinée au dépôt et à la diffusion de documents scientifiques de niveau recherche, publiés ou non, émanant des établissements d'enseignement et de recherche français ou étrangers, des laboratoires publics ou privés. 


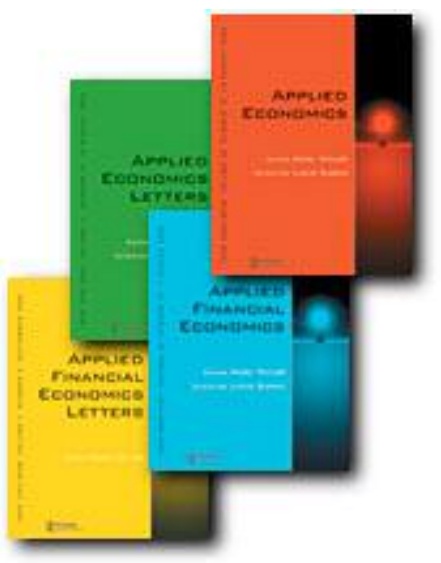

The effects of education on spouse's satisfaction in Europe

\begin{tabular}{|c|c|}
\hline Journal: & Applied Economics \\
\hline Manuscript ID: & APE-07-0492.R1 \\
\hline Journal Selection: & Applied Economics \\
\hline $\begin{array}{r}\text { Date Submitted by the } \\
\text { Author: }\end{array}$ & 20-May-2008 \\
\hline Complete List of Authors: & $\begin{array}{l}\text { Garcia, Inmaculada; University of Zaragoza } \\
\text { Molina, Jose Alberto; University of Zaragoza; Institute for the Study } \\
\text { of Labor-IZA } \\
\text { Navarro, María; FEDEA }\end{array}$ \\
\hline JEL Code: & $\begin{array}{l}\text { I20 - General < I2 - Education < I - Health, Education, and } \\
\text { Welfare, I31 - General Welfare|Basic Needs|Living } \\
\text { Standards|Quality of Life < I3 - Welfare and Poverty < I - Health, } \\
\text { Education, and Welfare, D10 - General < D1 - Household Behavior } \\
\text { and Family Economics < D - Microeconomics }\end{array}$ \\
\hline Keywords: & Education, Spouses, Income satisfaction, Europe \\
\hline
\end{tabular}

\section{S ScholaroNE \\ Manuscript Central}




\title{
The effects of education on spouses' satisfaction in Europe
}

\author{
INMACULADA GARCÍA $^{a}$, JOSE-ALBERTO MOLINA $^{b}$ and MARIA NAVARRO ${ }^{c}$ \\ ${ }^{a}$ Department of Economic Analysis, University of Zaragoza (Zaragoza, Spain) \\ ${ }^{b}$ Department of Economic Analysis, University of Zaragoza (Zaragoza, Spain), and Institute \\ for the Study of Labor-IZA (Bonn, Germany) \\ ${ }^{c}$ FEDEA (Madrid, Spain)
}

\begin{abstract}
This paper identifies the effects of both own and spouse's education levels on individual economic satisfaction for European households. To that end, it estimates several specifications based on the family collective approach, for each of the 14 EU countries, by using the eight waves of the European Community Household Panel-ECHP (1994-2001). After demonstrating that the IV Hausman-Taylor procedure is the selected estimation method in the majority of cases, the empirical results show that male and female income satisfaction significantly increases when the husband achieves higher education qualifications in the majority of European countries. However, the positive effect of the wife's higher education on female income satisfaction only appears in a very limited number of countries. Additionally, increases in individual wage and non-wage incomes generally lead to higher satisfaction levels.
\end{abstract}

Key words: Education, Spouses, Income satisfaction, Europe

JEL classification: I20, I31, D10

Correspondence: J.A. Molina. Department of Economic Analysis, University of Zaragoza, Zaragoza, Spain. Phone: 34976 761818, Fax: 34976 761996, E-mail: jamolina@unizar.es 


\section{INTRODUCTION}

The existing state of research on individual satisfaction suggests that reported subjective wellbeing is a satisfactory empirical approximation of individual utility, that can be applied in socio-economic research (Oswald, 1997; Easterlin, 2002; Frey and Stutzer, 2002; Hamermesh, 2004). The evidence adduced to date has shown that education appears to have a significant impact on the different satisfaction domains of individuals. For example, Van Praag et al., (2003) conclude that individuals with higher education are significantly more satisfied with their health, thus indicating that more highly educated individuals enjoy a healthier life style. Belfield and Harris (2002), Gazioglu and Tansel (2006) and Fleming and Kler (2007) also find a significant relationship between satisfaction and educational level. For their part, Clark and Oswald (1994 and 1996) and Clark et al. (1996) observe that highly educated people are less content with respect to their job satisfaction when other factors (income, etc.) are controlled for. The possible explanation here is that this low level of contentment might result from the significant reduction in income of those with lower qualifications. Ferrer-i-Carbonell and Van Praag (2003) produce ambiguous evidence for income satisfaction in Germany. On the one hand, they find that more education leads to more efficient consumption, which would appear to point to a positive effect on income satisfaction; on the other hand, more education widens the individual's horizon, thereby giving rise to increased expectations, which carries with it a negative effect as anticipated by neoclassical economic theory.

Despite the clear relevance of the evidence, the effects of education on satisfaction have usually been studied in a way that does not reflect the fact that the household is composed of interdependent spouses. The literature reflects only a limited number of exceptions to this approach. Thus, Schwarze (2004) finds that parental life satisfaction increases with a child's 
years of education. Health and education can serve as an approximation of income or future earnings, as has been confirmed in Blanchflower and Oswald (2004). In this way, if parents make some level of investment in their children's education while the children are still young, they can expect some returns when they become older. Thus, a positive impact of children's education on parental life satisfaction can also be driven by an exchange motive. Within couples, Groot and Maassen Van Den Brink (2002) study the effect of age and education differences between spouses on happiness, finding that female life satisfaction increases if the education gap between husband and wife is smaller.

In this line of modelling individual satisfaction within the household, as a fully interdependent process, this paper assumes the collective approach, in which one spouse's satisfaction not only depends on his/her own determinants, but also on the other spouse's variables, in order to model the effects of both own and spouse's education levels on individual economic satisfaction (Chiappori, 1988, 1992; Browning and Chiappori, 1998; Chiappori et al., 2002). Additionally, we also consider the influence of other individual and economic variables, such as age, the number of children, wages and non-wage incomes. The collective approach adopted in this paper makes it possible to derive some stochastic formulations which are then estimated for $14 \mathrm{EU}$ countries, using the panel structure which results from the eight waves of the European Community Household Panel-ECHP (19942001).

With respect to the estimation strategy, this takes the form of four consecutive estimations, namely pool, fixed effects, random effects and efficient generalized instrumental variables. The fixed or random effects methods correct the heterogeneity bias that appears when the use of subjective variables could imply that some people look at life either pessimistically or optimistically, even though there is "really" no difference in their level of well-being (Clark and Oswald, 2002; Ferrer-i-Carbonell and Frijters, 2004; Senik, 2004). 
Moreover, it is well known that individual behaviour is oriented towards achieving higher satisfaction levels. As a consequence, all the variables which can be chosen by individuals will be endogenous in the satisfaction regression, in such a way that the majority of estimated parameters obtained by standard regressions are likely to be underestimated. A standard solution to this endogeneity bias, which depends on the degree that individuals can choose their actions in order to be better off, is to use instrumental variables (Powdthavee, 2004; Schwarze, 2004). After carrying out all these estimations, the strategy selects the one that is statistically most appropriate in every case, by using the LM value, as well as two Hausman tests (Baltagi et al., 2003).

The rest of the paper is organized as follows. In the following section we describe the data. Next section is dedicated to the stochastic formulation. The following section is devoted to the empirical results and, finally, we close the paper with a summary of the most relevant conclusions.

\section{DATA}

Bearing in mind that the purpose of the study is to study the effects of both own and spouse's education levels on individual economic satisfaction, for individuals who work as wage earners, the data used in this work comes from the eight waves of the ECHP (1994-2001) for each of the 14 sample EU countries. ${ }^{1}$ In our study, households have been selected in which both spouses are aged between 16 and 65 years old. Individuals both with and without children have been included in these households. Those households lacking the required information have been excluded, resulting in two sub-samples, male wage earners and female

\footnotetext{
${ }^{1}$ The ECHP is an extensive, sample-based panel survey in which the same households and individuals are interviewed annually. The data come from a standardised questionnaire and are designed to be cross-nationally comparable (Peracchi, 2002).
} 
wage earners, with the number of observations ranging from France (17,623 husbands and 13,589 wives) to Luxembourg (1,288 husbands and 774 wives).

The ECHP includes questions about several subjective aspects of well-being, enquiring into the level of satisfaction that individuals reach with respect to different aspects, such as their income. The specific question this paper is interested in is: "How satisfied are you with your financial situation?". Each of these responses takes values from 1 to 6 , moving from not satisfied at all (1) to completely satisfied (6). This satisfaction question is based on individuals' own perception, in such a way that Table 1 begins by showing the simple means which are comparable across the populations, after assuming linearity across responses.

Table 1 shows the mean and standard deviation of the dependent variables used in the analysis. The dependent variables are husband and wife income satisfaction (HusbSatisf, WifeSatisf). Starting with the male sample, it can be appreciated that for male wage earners, these generally declare higher satisfaction levels than their respective wives in the majority of the sample countries, namely Austria, Belgium, Denmark, Finland, Germany, Greece, Italy, Portugal and Spain. With respect to the female sample, it emerges that female wage earners report higher satisfaction levels than their respective husbands, this being the case for all sample countries, save Portugal.

\section{(Table 1)}

With respect to the exogenous variables, the study includes both own and spouse's education levels (HusbPrimEduc, HusbSeconEduc, HusbHighEduc, WifePrimEduc, WifeSeconEduc, WifeHighEduc), as well as a number of individual characteristics and several economic variables. As regards individual characteristics, they include the age of the spouses (HusbAge, WifeAge), the age difference between the spouses (AgeDifference), as well as two other variables which refer to the presence of children in the household: a dummy variable 
indicating if there is a child under 12 in the household (Children $<12)$, and another indicating the number of children under $16($ Children $<16)$. Additionally, we include the percentages of self-employed and wage-earning wives in the husband's sample (WifeWage-Earner, WifeSelfEmployed), and the percentage of self-employed and wage-earning husbands in the wife's sample (HusbSelf-Employed, HusbWage-Earner). With respect to the variables which refer to the economic situation of the household, these include the wages of both spouses (HusbWage, WifeWage), as well as the annual non-wage incomes of both the husband and the wife (HusbNon-WageInc, WifeNon-WageInc), and the wife's participation in the household income (WifeParticipation).

Table 2 shows the mean and the standard deviation of each of the exogenous variables used in the analysis. As regards the education level, it can be noted in the majority of countries, and for both samples of wage-earners, that wives generally show a higher percentage than husbands for the primary education level. By contrast, the percentage of husbands who have attained higher education levels is generally greater than that corresponding to wives, with this evidence appearing generally in the male sample, but not at all in the female sample. The percentage of husbands who have secondary education is higher than that corresponding to wives who have attained this level, this being the case in both samples of male and female wage-earners, with the exceptions only of Germany and Ireland.

\section{(Table 2)}

In every sample country analysed, the age of the husband is greater than that of the wife in both samples of males and females. The age difference is greater for the female sample, with the highest mean value corresponding to Greece in both sample groups, where this age difference reaches 4.6 years. With respect to the variables that refer to the presence of children in the household, note that the percentages are higher in the male sample (where wives can be either wage-earners or self-employed) in the majority of the countries, namely in 
Austria, Denmark, Finland, France, Germany, Greece, Ireland, Italy, Luxembourg, the Netherlands, Spain and the United Kingdom, with the highest values corresponding to Austria. However, there appears to be clear evidence that the mean number of children under 16 is higher for the sample of male wage-earners than for the female sample, this being the case in every sample country.

From this simple descriptive analysis it also emerges that the husband's mean income per hour is higher than that of the wife's for both male and female wage-earners in every sample country. We can further note the smaller wage gap in the sample of female wageearners, and the highest values being reached for the male sample in Finland and Luxembourg. With respect to non-wage annual incomes, the wife's non-wage income is higher than that of the husband's in Austria, Belgium, Denmark, Finland, Germany, Greece, Ireland and the United Kingdom in the male wage earner sample. However, in the female wage-earner sample, the husband's non wage income is higher than that of the wife in every country, save Belgium and Denmark. Finally, note the higher percentage of wage-earner wives, as compared to self-employed wives, in the sample of male wage-earners and of female wage-earners, respectively, in all EU sample countries.

\section{THE MODEL}

This section develops the model specification and its estimation procedure. In order to describe the empirical specification to model the effects of both own and spouse's education levels on individual economic satisfaction, we first adopt the family collective approach. On the basis of the assumption that intra-household decisions are Pareto-efficient, this approach considers that the household consists of two working-age individuals, $A=$ husband and $B=$ wife, whose rational preferences could be represented by indirect utility functions, defined in 
terms of their own exogenous variables, as well as in terms of the other member's variables. Moreover, the panel data structure provided by the ECHP permits the application of techniques that help to control for unobservable heterogeneity. On these theoretical and empirical bases, the stochastic formulation underlying the observed subjective well-being responses takes the form of linear functions:

$v_{i t}^{I}=\mu_{i t}^{I}+\boldsymbol{\delta}_{1}^{A} E D_{i t}^{A}+\boldsymbol{\delta}_{2}^{B} E D_{i t}^{B}+\boldsymbol{\delta}_{3}^{A} z_{i t}^{A}+\boldsymbol{\delta}_{4}^{B} z_{i t}^{B}+\beta_{1}^{A} w_{i t}^{A}+\beta_{2}^{B} w_{i t}^{B}+\beta_{3}^{A} y_{i t}^{A}+\beta_{4}^{B} y_{i t}^{B}+\alpha_{i}^{I}+e_{i t}^{I}$

$$
i=1, \ldots, N ; t=1, \ldots, T ; I=A, B
$$

where $v_{i t}$ corresponds to the income subjective satisfaction of the individual $\mathrm{i}$ in period $\mathrm{t}$, with this $t$ being the current period, whereas an individual can be in the sample a maximum of $T$ periods. This dependent variable, $v_{i t,}$, is explained, according to the collective framework, by a number of exogenous variables. Thus, $E D_{i t}$ and $z_{i t}$ represent the education and other sociodemographic characteristics, respectively; $w_{i t}$ and $y_{i t}$ are wages and non-labour incomes; the parameters $\delta$ and $\beta$ represent the coefficients; $\mu$ and $\alpha$ are constant terms, with $\mu$ being the average population and $\alpha$ the individual deviation with respect to this average; and, finally, $e$ are the error terms that are supposed to be independent, with null mean and constant variance. These equations are estimated independently for both spouses, in such a way that $\mathrm{N}$ is the number of households in the sample.

The estimation strategy follows these steps. ${ }^{2}$ First, each equation is estimated separately, considering the aggregated data, that is to say, a pool estimation is carried out. A panel data structure is then used in order to estimate functions, considering individual effects, both fixed and random. As is well known, the difference between the two lies in the fact that, while, in

\footnotetext{
${ }^{2}$ Given the ordinal nature of the dependent variable on individual satisfaction, an appropriate regression model would be an ordered probit. However, while a random-effects ordered probit model is available in standard statistical software packages (Ferrer-i-Carbonell and Van Praag, 2003; Schwarze, 2004; Winkelmann, 2005), the fixed-effects ordered probit estimator is not. This is why the present paper uses as approximations both randomeffects and fixed-effects regression models, which are perfectly comparable by using habitual tests (D'Ambrosio and Frick, 2004; Ferrer-i-Carbonell and Frijters, 2004; Graham et al., 2004).
} 
the case of fixed effects, the $\alpha$ coefficients are considered as fixed values for each individual, in the specification of random effects, the specific aspects of each spouse are taken as independent random variables.

Consideration is also given to an alternative estimation procedure suggested in the literature, namely the Efficient Generalized Instrumental Variables (EGIV), proposed by Hausman and Taylor (1981). ${ }^{3}$ The method followed in this paper uses as instruments the individual time averages of the variables (the individual's own wage, the presence of children under 12 , the number of children under 16 , the spouse's own wage, male and female nonlabour income, the wife's participation in household income, own age and a dummy that indicates if the individual is self-employed) for the time-invariant variables that are correlated with the individual effects (the age difference between the spouses, the individual's own education levels, and the spouse's higher education level). Thus, this procedure allows for the simultaneous control of the correlation between regressors and unobserved individual effects, by using instruments. Similarly, it permits the identification of the estimates of the timeinvariant covariates, such as education. Moreover, it avoids the insecurity associated with the choice of suitable instruments, since the individual means over time of all the included regressors can serve as valid instruments. Additionally, the variance-covariance structure can be taken into account so as to obtain more efficient estimators.

This EGIV method is implemented in the following steps. First, equations (1) are estimated by pooled Two Stage Least Squares (2SLS), where the set of variables mentioned above act as instruments. Second, the pooled 2SLS residuals are used to construct the weights for a Feasible Generalized Least Squares estimator. Third, these weights are used to transform (by quasi-time demeaning) all the dependent variables, explanatory variables and instrumental

\footnotetext{
${ }^{3}$ The recent work by Baltagi et al., (2003) provides information on the suitability of the Hausman-Taylor procedure in a general framework where panel data is available and some regressors are correlated with the individual effects.
} 
variables. Finally, the transformed regression is again estimated by pooled 2SLS, where the individual means over time of the time-varying regressors, and the exogenous time-invariant regressors, are the instruments. Under the full set of assumptions, this Hausman and Taylor estimator coincides with the efficient GMM estimator.

After estimating the four alternative specifications, some appropriate econometric tests allow for the best formulation to be selected in every case. In particular, an LM test indicates if a panel or a pool estimation is preferred. If a panel estimation is selected, then a choice must be made from among the three alternative specifications, with two Hausman tests allowing the best panel estimation to be selected (Hausman, 1978). ${ }^{4}$ The first Hausman test (Hausman-1) is the standard to distinguish between the random and fixed effects estimators, and the second (Hausman-2) tests the Hausman-Taylor against the fixed effects model. ${ }^{5}$

\section{EMPIRICAL RESULTS}

Table 3 includes the empirical results for both sub-samples, male wage earners and female wage earners. We begin with a brief description of the test results that allows us to select a particular estimation procedure for each sample country. First, the LM tests indicate that the pool estimation is not selected in any sample country. Second, Hausman-1 tests reveal that the fixed effects estimation is preferred over random effects and, third, Hausman-2 tests indicate that, for all cases, save for male wage earners in Austria, the Hausman-Taylor estimation is preferred over the fixed effects.

(Table 3)

\footnotetext{
${ }_{5}^{4}$ See, for details, Hausman and Taylor (1981), Wooldridge (2002) and Baltagi, Bresson and Pirotte (2003).

${ }^{5}$ The 8.0 version of Stata includes the Hausman-Taylor procedure and is used to obtain the estimates presented in this paper
} 
With respect to the education variables, we show that income satisfaction significantly increases when husbands achieve higher education qualifications, with this result appearing in a significant number of cases, particularly Finland, Germany, Greece, Italy, Portugal, Spain, the Netherlands and the United Kingdom. Similar results have been obtained in Ferrer-iCarbonell and Van Praag (2003); Van Praag, Frijters and Ferrer-i-Carbonell (2003) and Frijters, Haisken-DeNew and Shields (2004). As regards the effect of a wife's higher education on her husband's income satisfaction, this appears to increase in France, which can be interpreted as that the wife can better appreciate the necessary effort of her husband to reach a certain level of income and, therefore, according to the cooperative nature of the relationship between spouses, this assessment increases the husband's satisfaction with respect to his level of income. By contrast, the effect decreases in Finland and Germany, where the wife's higher education does not imply a higher assessment of her spouse's effort to reach a certain level of income.

Wives' higher education increases income satisfaction of wives in Greece, Ireland and Portugal. The wife is affected more than the husband by the spouse's education level, in such a way that income satisfaction is increased when the husband has received higher education, in the cases of Austria, Belgium, Denmark, the Netherlands, Portugal and the United Kingdom. Groot and Maasen Van Den Brink (2002) find that husbands typically tend to be older and higher educated than their wives. Education differences between spouses can effect marital stability and divorce rates, in such a way that life satisfaction increases when the education gap is smaller. This is also the case of Finland and Germany, where we can note that the effect of the wife's education on the husband's satisfaction runs in the opposite direction.

Additionally, we can observe that the effect of age is significantly positive for male wage earners in the majority of countries, namely Austria, Belgium, Finland, France, Greece, 
Ireland, Luxembourg, the Netherlands, Portugal and Spain. This same result appears for the wife's age in the female samples of Belgium, Denmark, Finland, France, Greece, Ireland, The Netherlands, Spain and the United Kingdom. Groot and Maasen Van Den Brink (2002) find that a positive age gap between husband and wife increases both male and female satisfaction, and we find an increase in female satisfaction in Finland and Greece. The effects of the presence of children vary across countries, also depending on age. Thus, we find that if the child is under 12, then the effect is positive in Spain and negative in Austria, Denmark, France and the Netherlands for male wage earners. For the female sample, we can observe the same result and, in addition, a negative effect in Italy and the United Kingdom, but a positive effect in Greece. Moreover, if the age is less than 16 years, then the effect is positive for male wage-earners in France and Luxembourg, and negative in Belgium, Denmark, Germany, Greece, Italy, Spain and the United Kingdom. For the female sample, it is similarly negative in Denmark, Greece, Ireland and the United Kingdom, but positive in France.

Turning to the economic variables, it can be observed that increases in the husband's wage has, according to the normality assumption, a highly significant positive impact on male satisfaction for the majority of cases, particularly for both samples in Austria, France, Germany, Greece, Italy, Portugal and Spain. Moreover, this same positive effect from the wife's wage is also observable for both samples in France, Greece and Portugal. For their part, Belgium, France, Greece, Italy, Portugal and Spain show altruistic behaviour with respect to wage incomes, in such a way that male satisfaction positively depends on female wages, and female satisfaction on male wages. By contrast, all male workers in Austria, Finland, Germany, Ireland, Luxembourg and the United Kingdom exhibit egoistic behaviour, with their utilities remaining indifferent to changes in their wives' labour incomes. With respect to non-wage incomes, the husband's variable has a clearly positive effect on male and female income satisfaction in Greece and Portugal. Finally, it can be noted that increases in 
the female's share of household income increases male income satisfaction in Finland, Ireland, Luxembourg and the Netherlands, and decreases it in Belgium and the United Kingdom. Finally, note that when the wife's participation in household income increases, so her satisfaction increases in the cases of Italy, Portugal and the United Kingdom.

\section{CONCLUSIONS}

This paper has analysed the effects of both own and spouse's education levels, as well as other individual and economic variables, on economic satisfaction for the case of European households. To that end, we have assumed a collective family model framework, whose empirical specifications (pool, fixed effects, random effects and efficient generalized instrumental variables) have been estimated using the eight waves of the ECHP (1994-2001).

With respect to the selected formulation, the empirical results show that the IV Hausman-Taylor estimator has been selected in the majority of cases. As regards the relevant variables for this article, male income satisfaction significantly increases when the husband achieves higher education qualifications in Finland, Germany, Greece, Italy, The Netherlands, Portugal, Spain and the United Kingdom. Female income satisfaction is positively related to her education level in Greece, Ireland and Portugal; and, additionally, to the husband's education level in Austria, Belgium, Denmark, Finland, Germany, the Netherlands, Portugal and the United Kingdom.

As regards other determinants, age has a significantly positive impact on income satisfaction for wage earners in the majority of countries. With respect to the economic variables, it first appears that increases in individual wage and non-wage incomes lead to higher satisfaction levels. Moreover, with respect to interrelations between spouses, our results reveal that in France, Greece and Portugal, all workers, whether male or female, show 
altruistic behaviour with respect to wage incomes, while in Finland, both male and female workers exhibit egoistic behaviour.

An understanding of individual satisfaction derived from income within the household could be particularly useful for policy-makers in evaluating socio-economic policies. Thus, the empirical conclusions drawn from this study will hopefully assist in the drafting of such policies, that have the objective of increasing the satisfaction levels reported by the spouses within the household.

There appears to be support for such policies, e.g. the reduction in class sizes, that has been shown to improve children's education outcomes (Bingley et al., 2005). Moreover, while it is clear that both genders have benefited from progress in the sphere of education, these advances have failed to eradicate the gender gap. Compulsory education laws are not sufficient to equalize attendance rates, so special policies should be enacted aimed at increasing the number of women benefiting from education, such as building more schools in remote rural areas, or providing correspondence courses. However, the costs associated with school attendance, as well as opportunity costs, are high and the perceived benefit of formal education for girls is low, which could reduce the demand for education on the part of some groups in certain developing countries.

\section{ACKNOWLEDGEMENTS}

This paper was partially written while José Alberto Molina was Visiting Fellow at the Department of Economics of the University of Warwick (UK), to which he would like to express his thanks for the hospitality and facilities provided. An earlier version of this paper has been presented at the Spanish Economic Analysis Meeting-2004 (Pamplona, Spain), as well as at the Department of Economics of the University of Warwick-2005 (Warwick, UK), 
with all the comments made by the participants, particularly those of Ian Walker, being highly appreciated. Moreover, the authors would like to express their thanks to one anonymous referee for helpful comments and suggestions. Thanks are due also for the financial support provided by the Spanish Ministry of Education and Science and FEDER (Project SEC200506522), by the BBVA Foundation and the DGA. The usual disclaimer applies. 


\section{REFERENCES}

Baltagi, B. H., Bresson, G., and Pirotte, A. (2003) Fixed effects, random effects or HausmanTaylor? A pretest estimator. Economics Letters, 79, 361-369.

Belfield, C.R. and Harris, R.D.F. (2002) How well do theories of job matching explain variations in job satisfaction across education levels? Evidence for UK graduates. Applied Economics, 34, 535-548.

Bingley, P., Myrup Jensen, V., and Walker, I. (2005) The effects of school resources on participation in post-compulsory education: Danish quasi-experimental evidence, and evidence that controls for family, school and neighbourhood effects. Mimeo.

Blanchflower, D. G., and Oswald, A. J. (2004) Well-being over Time in Britain and the USA. Journal of Public Economics, 88, 1359-1386.

Browning, M., and Chiappori, P-A. (1998) Efficient intra-household allocations: a general characterization and empirical tests. Econometrica, 66, 1241-1278.

Chiappori, P-A. (1988) Rational household labour supply. Econometrica, 56, 63-89.

Chiappori, P-A. (1992) Collective labour supply and welfare. Journal of Political Economy, 100, $437-467$.

Chiappori, P-A., Fortin, B., and Lacroix, G. (2002) Divorce legislation and household labour supply. Journal of Political Economy, 110, 37-71.

Clark, A. E., and Oswald, A. J. (1994) Unhappiness and unemployment. Economic Journal, 104(424), 648-659.

Clark, A. E., and Oswald, A. J. (1996). Satisfaction and Comparison Income. Journal of Public Economics, 61, 359-381. 
Clark, A. E., and Oswald, A. J. (2002) A simple statistical method for measuring how life events affect happiness. International Journal of Epidemiology, 31, 1139-1144.

Clark, A.E., Oswald, A.J. and Warr, P. (1996) Is Job Satisfaction U-shaped in Age? Journal of Occupational and Organizational Psychology, 69, 57-81.

D’Ambrosio, C., and Frick, J. R. (2004) Subjective well-being and relative deprivation: an empirical link. IZA Discussion Paper Series, No. 1351.

Easterlin, R.A. (2002) Happiness in Economics. Edward Elgar.

Ferrer-i-Carbonell, A. and Frijters, P. (2004) How Important is Methodology for the Estimates of the determinants of Happiness? Economic Journal, 114, 641-659.

Ferrer-i-Carbonell, A. and Van Praag, B. (2003) Income Satisfaction Inequality and its Causes. Journal of Economic Inequality, 1, 107-127.

Fleming, C. M. and Kler, P. (2007) I'm too clever for this job: a bivariate probit analysis on overeducation and job satisfaction in Australia. Applied Economics, 40, 1123-1138.

Frey, B.S., and Stutzer, A. (2002) What can Economists Learn from Happiness Research? Journal of Economic Literature, 40, 402-435.

Frijters, P., Haisken-DeNew, J., and Shields, M. (2004) Money does Matter! Evidence from Increasing Real Incomes and Life Satisfaction in East Germany following Reunification. American Economic Review, 94, 730-740.

Gazioglu, S. and Tansel, A. (2006) Job satisfaction in Britain: individual and job related factors. Applied Economics, 38, 1163-1171.

Graham, C., Eggers, A., and Sukhtankar, S. (2004) Does happiness pay? An exploration based on panel data from Russia. Journal of Economic Behavior and Organization, 55, $319-342$. 
Groot, W., and Maassen van den Brink, H. (2002) Age and education differences in marriages and their effects on life satisfaction. Journal of Happiness Studies, 3, 153-165.

Hamermesh, D.S. (2004) Subjective outcomes in economics. Southern Economic Journal, 71, 1-11.

Hausman, J. A. (1978) Specification tests in econometrics. Econometrica, 46, 1251-1271.

Hausman, J. A., and Taylor, W. E. (1981) Panel data and unobservable individual effects. Econometrica, 49, 1377-1398.

Oswald, A.J. (1997) Happiness and Economic Performance. Economic Journal, 107, 18151831.

Peracchi, F. (2002) The European Community Household Panel: a review. Empirical Economics, 27, 63-90.

Powdthavee, N. (2004) Mental risk-sharing in marriage: evidence from panel data. The Warwick Economics Research Paper Series No 798.

Schwarze, J. (2004) Living Conditions of Children and Parental Well-being: Evidence from German Data on Life Satisfaction. IZA Discussion Paper Series, No. 1200.

Senik, C. (2004) Relativizing relative income. DELTA Working Paper, No. 2004-17.

Van Praag, B., Frijters, P. and Ferrer-i-Carbonell, A. (2003) The Anatomy of subjective wellbeing. Journal of Economic Behavior and Organization, 51, 29-49.

Winkelmann, R. (2005) Subjective well-being and the family: results from an ordered probit model with multiple random effects. Empirical Economics, 30, 749-761.

Wooldridge, J. M. (2002) Econometric Analysis of Cross-Section and Panel Data. MIT Press. 
Table 1. Mean and std. dev of dependent variables of husbands and wives

\begin{tabular}{|c|c|c|c|c|c|c|c|c|c|c|c|c|c|c|}
\hline & Austria & Belgium & Denmark & Finland & France & Germany & Greece & Ireland & Italy & Luxembourg & $\begin{array}{c}\text { The } \\
\text { Netherlands }\end{array}$ & Portugal & Spain & $\begin{array}{c}\text { United- } \\
\text { Kingdom } \\
\end{array}$ \\
\hline \multicolumn{15}{|l|}{ Husbands } \\
\hline HusbIncSatisf & $\begin{array}{l}4.327 \\
(1.21)\end{array}$ & $\begin{array}{l}4.159 \\
(1.14)\end{array}$ & $\begin{array}{l}4.635 \\
(1.05)\end{array}$ & $\begin{array}{l}4.093 \\
(1.08)\end{array}$ & $\begin{array}{l}3.698 \\
(1.16)\end{array}$ & $\begin{array}{l}3.915 \\
(1.16)\end{array}$ & $\begin{array}{l}3.319 \\
(1.13)\end{array}$ & $\begin{array}{l}3.819 \\
(1.32)\end{array}$ & $\begin{array}{l}3.403 \\
(1.20)\end{array}$ & $\begin{array}{l}4.252 \\
(1.25)\end{array}$ & $\begin{array}{l}4.619 \\
(0.93)\end{array}$ & $\begin{array}{l}3.259 \\
(0.99)\end{array}$ & $\begin{array}{l}3.419 \\
(1.28)\end{array}$ & $\begin{array}{l}3.896 \\
(1.06)\end{array}$ \\
\hline WifeIncSatisf & $\begin{array}{l}4.256 \\
(1.35)\end{array}$ & $\begin{array}{l}4.157 \\
(1.22)\end{array}$ & $\begin{array}{l}4.580 \\
(1.16)\end{array}$ & $\begin{array}{l}4.067 \\
(1.16)\end{array}$ & $\begin{array}{l}3.703 \\
(1.20)\end{array}$ & $\begin{array}{l}3.847 \\
(1.26)\end{array}$ & $\begin{array}{l}3.165 \\
(1.14)\end{array}$ & $\begin{array}{l}3.910 \\
(1.37)\end{array}$ & $\begin{array}{l}3.292 \\
(1.24)\end{array}$ & $\begin{array}{l}4.327 \\
(1.27)\end{array}$ & $\begin{array}{l}4.706 \\
(0.95)\end{array}$ & $\begin{array}{l}3.071 \\
(1.03)\end{array}$ & $\begin{array}{l}3.385 \\
(1.31)\end{array}$ & $\begin{array}{l}3.993 \\
(1.06)\end{array}$ \\
\hline Number of observations & 7615 & 8284 & 8356 & 6280 & 17623 & 5764 & 8814 & 5295 & 17344 & 1288 & 16442 & 13612 & 15524 & 8427 \\
\hline \multicolumn{15}{|l|}{ Wives } \\
\hline HusbIncSatisf & $\begin{array}{l}4.235 \\
(1.30)\end{array}$ & $\begin{array}{l}4.086 \\
(1.16)\end{array}$ & $\begin{array}{l}4.594 \\
(1.09)\end{array}$ & $\begin{array}{l}4.065 \\
(1.14)\end{array}$ & $\begin{array}{l}3.738 \\
(1.16)\end{array}$ & $\begin{array}{l}3.868 \\
(1.20)\end{array}$ & $\begin{array}{l}3.388 \\
(1.20)\end{array}$ & $\begin{array}{l}3.774 \\
(1.37)\end{array}$ & $\begin{array}{l}3.612 \\
(1.20)\end{array}$ & $\begin{array}{l}4.149 \\
(1.30)\end{array}$ & $\begin{array}{l}4.624 \\
(0.96)\end{array}$ & $\begin{array}{l}3.261 \\
(1.02)\end{array}$ & $\begin{array}{l}3.469 \\
(1.33)\end{array}$ & $\begin{array}{l}3.859 \\
(1.08)\end{array}$ \\
\hline WifeIncSatisf & $\begin{array}{l}4.389 \\
(1.26)\end{array}$ & $\begin{array}{l}4.208 \\
(1.11)\end{array}$ & $\begin{array}{l}4.641 \\
(1.10)\end{array}$ & $\begin{array}{l}4.170 \\
(1.09)\end{array}$ & $\begin{array}{l}3.826 \\
(1.10)\end{array}$ & $\begin{array}{l}3.897 \\
(1.22)\end{array}$ & $\begin{array}{l}3.393 \\
(1.15)\end{array}$ & $\begin{array}{l}3.967 \\
(1.31)\end{array}$ & $\begin{array}{l}3.617 \\
(1.18)\end{array}$ & $\begin{array}{l}4.278 \\
(1.27)\end{array}$ & $\begin{array}{l}4.739 \\
(0.93)\end{array}$ & $\begin{array}{l}3.221 \\
(0.99)\end{array}$ & $\begin{array}{l}3.559 \\
(1.31)\end{array}$ & $\begin{array}{l}3.996 \\
(1.03)\end{array}$ \\
\hline Number of observations & 5523 & 6604 & 7790 & 6513 & 13589 & 4399 & 4884 & 3800 & 10403 & 774 & 12218 & 10271 & 7600 & 7839 \\
\hline
\end{tabular}


Table 2. Mean and std. dev of exogenous variables of husbands and wives

\begin{tabular}{|c|c|c|c|c|c|c|c|c|c|c|c|c|c|c|}
\hline & Austria & Belgium & Denmark & Finland & France & Germany & Greece & Ireland & Italy & Luxembourg & $\begin{array}{c}\text { The } \\
\text { Netherlands }\end{array}$ & Portugal & Spain & $\begin{array}{c}\text { United- } \\
\text { Kingdom } \\
\end{array}$ \\
\hline \multicolumn{15}{|l|}{ Husbands } \\
\hline HusbPrimEduc & $\begin{array}{l}0.123 \\
(0.33)\end{array}$ & $\begin{array}{l}0.227 \\
(0.42)\end{array}$ & $\begin{array}{l}0.190 \\
(0.39)\end{array}$ & $\begin{array}{l}0.188 \\
(0.39)\end{array}$ & $\begin{array}{l}0.272 \\
(0.44)\end{array}$ & $\begin{array}{l}0.175 \\
(0.38)\end{array}$ & $\begin{array}{c}0.428 \\
(0.49)\end{array}$ & $\begin{array}{l}0.391 \\
(0.49)\end{array}$ & $\begin{array}{l}0.486 \\
(0.50)\end{array}$ & $\begin{array}{l}0.484 \\
(0.50)\end{array}$ & $\begin{array}{l}0.213 \\
(0.41)\end{array}$ & $\begin{array}{l}0.823 \\
(0.38)\end{array}$ & $\begin{array}{c}0.579 \\
(0.49)\end{array}$ & $\begin{array}{l}0.354 \\
(0.48)\end{array}$ \\
\hline HusbSeconEduc & $\begin{array}{l}0.780 \\
(0.41)\end{array}$ & $\begin{array}{l}0.324 \\
(0.47)\end{array}$ & $\begin{array}{l}0.426 \\
(0.49)\end{array}$ & $\begin{array}{l}0.447 \\
(0.50)\end{array}$ & $\begin{array}{l}0.434 \\
(0.50)\end{array}$ & $\begin{array}{l}0.493 \\
(0.50)\end{array}$ & $\begin{array}{l}0.281 \\
(0.45)\end{array}$ & $\begin{array}{l}0.371 \\
(0.48)\end{array}$ & $\begin{array}{l}0.379 \\
(0.49)\end{array}$ & $\begin{array}{l}0.286 \\
(0.45)\end{array}$ & $\begin{array}{l}0.527 \\
(0.50)\end{array}$ & $\begin{array}{l}0.102 \\
(0.30)\end{array}$ & $\begin{array}{l}0.174 \\
(0.38)\end{array}$ & $\begin{array}{l}0.226 \\
(0.42)\end{array}$ \\
\hline HusbHighEduc & $\begin{array}{l}0.089 \\
(0.29)\end{array}$ & $\begin{array}{l}0.369 \\
(0.48)\end{array}$ & $\begin{array}{l}0.378 \\
(0.48)\end{array}$ & $\begin{array}{l}0.360 \\
(0.48)\end{array}$ & $\begin{array}{l}0.235 \\
(0.42)\end{array}$ & $\begin{array}{l}0.331 \\
(0.47)\end{array}$ & $\begin{array}{l}0.287 \\
(0.45)\end{array}$ & $\begin{array}{l}0.227 \\
(0.42)\end{array}$ & $\begin{array}{l}0.107 \\
(0.31)\end{array}$ & $\begin{array}{l}0.228 \\
(0.42)\end{array}$ & $\begin{array}{l}0.242 \\
(0.43)\end{array}$ & $\begin{array}{l}0.063 \\
(0.24)\end{array}$ & $\begin{array}{l}0.247 \\
(0.43)\end{array}$ & $\begin{array}{l}0.404 \\
(0.49)\end{array}$ \\
\hline WifePrimEduc & $\begin{array}{l}0.271 \\
(0.44)\end{array}$ & $\begin{array}{l}0.243 \\
(0.43)\end{array}$ & $\begin{array}{l}0.216 \\
(0.41)\end{array}$ & $\begin{array}{l}0.183 \\
(0.39)\end{array}$ & $\begin{array}{l}0.315 \\
(0.46)\end{array}$ & $\begin{array}{l}0.307 \\
(0.46)\end{array}$ & $\begin{array}{l}0.520 \\
(0.50)\end{array}$ & $\begin{array}{l}0.392 \\
(0.49)\end{array}$ & $\begin{array}{l}0.508 \\
(0.50)\end{array}$ & $\begin{array}{l}0.595 \\
(0.49)\end{array}$ & $\begin{array}{l}0.294 \\
(0.46)\end{array}$ & $\begin{array}{l}0.806 \\
(0.40)\end{array}$ & $\begin{array}{l}0.635 \\
(0.48)\end{array}$ & $\begin{array}{l}0.446 \\
(0.50)\end{array}$ \\
\hline WifeSeconEduc & $\begin{array}{l}0.631 \\
(0.48)\end{array}$ & $\begin{array}{l}0.299 \\
(0.46)\end{array}$ & $\begin{array}{l}0.399 \\
(0.49)\end{array}$ & $\begin{array}{l}0.381 \\
(0.49)\end{array}$ & $\begin{array}{l}0.375 \\
(0.48)\end{array}$ & $\begin{array}{l}0.551 \\
(0.50)\end{array}$ & $\begin{array}{l}0.243 \\
(0.43)\end{array}$ & $\begin{array}{l}0.430 \\
(0.50)\end{array}$ & $\begin{array}{l}0.374 \\
(0.48)\end{array}$ & $\begin{array}{l}0.282 \\
(0.45)\end{array}$ & $\begin{array}{l}0.517 \\
(0.50)\end{array}$ & $\begin{array}{l}0.099 \\
(0.30)\end{array}$ & $\begin{array}{l}0.170 \\
(0.38)\end{array}$ & $\begin{array}{l}0.243 \\
(0.43)\end{array}$ \\
\hline WifeHighEduc & $\begin{array}{l}0.084 \\
(0.28)\end{array}$ & $\begin{array}{l}0.393 \\
(0.49)\end{array}$ & $\begin{array}{l}0.378 \\
(0.48)\end{array}$ & $\begin{array}{l}0.433 \\
(0.50)\end{array}$ & $\begin{array}{l}0.241 \\
(0.43)\end{array}$ & $\begin{array}{l}0.139 \\
(0.35)\end{array}$ & $\begin{array}{l}0.235 \\
(0.42)\end{array}$ & $\begin{array}{l}0.167 \\
(0.37)\end{array}$ & $\begin{array}{l}0.088 \\
(0.28)\end{array}$ & $\begin{array}{l}0.119 \\
(0.32)\end{array}$ & $\begin{array}{l}0.176 \\
(0.38)\end{array}$ & $\begin{array}{l}0.064 \\
(0.24)\end{array}$ & $\begin{array}{l}0.195 \\
(0.40)\end{array}$ & $\begin{array}{l}0.303 \\
(0.46)\end{array}$ \\
\hline HusbAge & $\begin{array}{c}41.602 \\
(9.56)\end{array}$ & $\begin{array}{c}41.095 \\
(9.04)\end{array}$ & $\begin{array}{l}41.893 \\
(11.14)\end{array}$ & $\begin{array}{c}41.394 \\
(9.97)\end{array}$ & $\begin{array}{c}40.685 \\
(9.53)\end{array}$ & $\begin{array}{l}43.079 \\
(10.15)\end{array}$ & $\begin{array}{c}43.163 \\
(9.66)\end{array}$ & $\begin{array}{l}43.310 \\
(10.19)\end{array}$ & $\begin{array}{c}43.082 \\
(9.29)\end{array}$ & $\begin{array}{c}39.958 \\
(9.03)\end{array}$ & $\begin{array}{c}41.769 \\
(9.33)\end{array}$ & $\begin{array}{l}42.187 \\
(11.48)\end{array}$ & $\begin{array}{r}42.015 \\
(9.87)\end{array}$ & $\begin{array}{l}41.614 \\
(10.97)\end{array}$ \\
\hline WifeAge & $\begin{array}{c}39.127 \\
(9.53)\end{array}$ & $\begin{array}{l}39.038 \\
(9.23)\end{array}$ & $\begin{array}{l}39.621 \\
(10.99)\end{array}$ & $\begin{array}{l}39.761 \\
(10.11)\end{array}$ & $\begin{array}{c}38.580 \\
(9.69)\end{array}$ & $\begin{array}{l}40.534 \\
(10.01)\end{array}$ & $\begin{array}{l}38.690 \\
(9.71)\end{array}$ & $\begin{array}{l}41.323 \\
(10.04)\end{array}$ & $\begin{array}{l}39.945 \\
(9.23)\end{array}$ & $\begin{array}{c}37.231 \\
(8.84)\end{array}$ & $\begin{array}{c}39.468 \\
(9.41)\end{array}$ & $\begin{array}{l}39.563 \\
(11.33)\end{array}$ & $\begin{array}{c}39.561 \\
(9.71)\end{array}$ & $\begin{array}{l}39.669 \\
(10.98)\end{array}$ \\
\hline AgeDifference & $\begin{array}{l}2.489 \\
(4.15)\end{array}$ & $\begin{array}{l}2.057 \\
(3.84)\end{array}$ & $\begin{array}{l}2.264 \\
(4.22)\end{array}$ & $\begin{array}{l}1.629 \\
(3.76)\end{array}$ & $\begin{array}{l}2.110 \\
(4.30)\end{array}$ & $\begin{array}{l}2.547 \\
(3.94)\end{array}$ & $\begin{array}{l}4.664 \\
(4.25)\end{array}$ & $\begin{array}{l}1.989 \\
(3.60)\end{array}$ & $\begin{array}{l}3.154 \\
(3.64)\end{array}$ & $\begin{array}{l}2.742 \\
(4.16)\end{array}$ & $\begin{array}{l}2.296 \\
(3.71)\end{array}$ & $\begin{array}{l}2.614 \\
(4.42)\end{array}$ & $\begin{array}{l}2.493 \\
(3.56)\end{array}$ & $\begin{array}{l}1.962 \\
(4.63)\end{array}$ \\
\hline Children $<12$ & $\begin{array}{l}0.476 \\
(0.50)\end{array}$ & $\begin{array}{l}0.354 \\
(0.48)\end{array}$ & $\begin{array}{l}0.363 \\
(0.48)\end{array}$ & $\begin{array}{l}0.450 \\
(0.50)\end{array}$ & $\begin{array}{l}0.428 \\
(0.49)\end{array}$ & $\begin{array}{l}0.272 \\
(0.45)\end{array}$ & $\begin{array}{l}0.413 \\
(0.49)\end{array}$ & $\begin{array}{l}0.432 \\
(0.50)\end{array}$ & $\begin{array}{l}0.412 \\
(0.49)\end{array}$ & $\begin{array}{l}0.367 \\
(0.48)\end{array}$ & $\begin{array}{l}0.374 \\
(0.48)\end{array}$ & $\begin{array}{l}0.401 \\
(0.49)\end{array}$ & $\begin{array}{l}0.401 \\
(0.49)\end{array}$ & $\begin{array}{l}0.333 \\
(0.47)\end{array}$ \\
\hline Children $<16$ & $\begin{array}{l}0.978 \\
(1.01)\end{array}$ & $\begin{array}{l}1.117 \\
(1.12)\end{array}$ & $\begin{array}{l}0.914 \\
(1.04)\end{array}$ & $\begin{array}{l}1.082 \\
(1.17)\end{array}$ & $\begin{array}{l}1.092 \\
(1.11)\end{array}$ & $\begin{array}{l}0.899 \\
(1.03)\end{array}$ & $\begin{array}{l}1.060 \\
(0.96)\end{array}$ & $\begin{array}{l}1.471 \\
(1.34)\end{array}$ & $\begin{array}{l}0.930 \\
(0.91)\end{array}$ & $\begin{array}{l}1.203 \\
(1.08)\end{array}$ & $\begin{array}{l}1.006 \\
(1.11)\end{array}$ & $\begin{array}{l}0.971 \\
(1.04)\end{array}$ & $\begin{array}{l}0.958 \\
(0.95)\end{array}$ & $\begin{array}{l}0.920 \\
(1.06)\end{array}$ \\
\hline WifeSelf-Employed & $\begin{array}{l}0.064 \\
(0.25)\end{array}$ & $\begin{array}{l}0.054 \\
(0.23)\end{array}$ & $\begin{array}{l}0.025 \\
(0.16)\end{array}$ & $\begin{array}{l}0.047 \\
(0.21)\end{array}$ & $\begin{array}{l}0.026 \\
(0.16)\end{array}$ & $\begin{array}{l}0.028 \\
(0.17)\end{array}$ & $\begin{array}{l}0.080 \\
(0.27)\end{array}$ & $\begin{array}{l}0.030 \\
(0.17)\end{array}$ & $\begin{array}{l}0.037 \\
(0.19)\end{array}$ & $\begin{array}{l}0.027 \\
(0.16)\end{array}$ & $\begin{array}{l}0.027 \\
(0.16)\end{array}$ & $\begin{array}{l}0.070 \\
(0.26)\end{array}$ & $\begin{array}{l}0.039 \\
(0.19)\end{array}$ & $\begin{array}{l}0.039 \\
(0.19)\end{array}$ \\
\hline WifeWage-Earner & $\begin{array}{l}0.565 \\
(0.50)\end{array}$ & $\begin{array}{l}0.655 \\
(0.48)\end{array}$ & $\begin{array}{l}0.786 \\
(0.41)\end{array}$ & $\begin{array}{l}0.738 \\
(0.44)\end{array}$ & $\begin{array}{l}0.609 \\
(0.49)\end{array}$ & $\begin{array}{l}0.624 \\
(0.48)\end{array}$ & $\begin{array}{l}0.356 \\
(0.48)\end{array}$ & $\begin{array}{l}0.501 \\
(0.50)\end{array}$ & $\begin{array}{l}0.417 \\
(0.49)\end{array}$ & $\begin{array}{l}0.500 \\
(0.50)\end{array}$ & $\begin{array}{l}0.649 \\
(0.48)\end{array}$ & $\begin{array}{l}0.557 \\
(0.50)\end{array}$ & $\begin{array}{l}0.343 \\
(0.47)\end{array}$ & $\begin{array}{l}0.710 \\
(0.45)\end{array}$ \\
\hline HusbWage & $\begin{array}{l}10.046 \\
(5.17)\end{array}$ & $\begin{array}{l}9.854 \\
(4.80)\end{array}$ & $\begin{array}{l}10.833 \\
(6.17)\end{array}$ & $\begin{array}{l}14.039 \\
(8.92)\end{array}$ & $\begin{array}{l}9.657 \\
(8.68)\end{array}$ & $\begin{array}{l}10.733 \\
(6.25)\end{array}$ & $\begin{array}{l}5.281 \\
(3.51)\end{array}$ & $\begin{array}{c}9.997 \\
(11.903)\end{array}$ & $\begin{array}{l}0.007 \\
(0.00)\end{array}$ & $\begin{array}{l}14.296 \\
(7.13)\end{array}$ & $\begin{array}{l}10.546 \\
(14.68)\end{array}$ & $\begin{array}{l}3.808 \\
(3.04)\end{array}$ & $\begin{array}{l}6.421 \\
(4.22)\end{array}$ & $\begin{array}{l}7.638 \\
(6.28)\end{array}$ \\
\hline WifeWage & $\begin{array}{l}4.165 \\
(5.67)\end{array}$ & $\begin{array}{l}5.560 \\
(5.19)\end{array}$ & $\begin{array}{l}7.269 \\
(5.41)\end{array}$ & $\begin{array}{c}8.020 \\
(10.12)\end{array}$ & $\begin{array}{l}4.857 \\
(6.69)\end{array}$ & $\begin{array}{l}4.255 \\
(6.32)\end{array}$ & $\begin{array}{l}1.728 \\
(2.93)\end{array}$ & $\begin{array}{c}3.766 \\
(6.521)\end{array}$ & $\begin{array}{l}0.003 \\
(0.00)\end{array}$ & $\begin{array}{l}5.664 \\
(8.31)\end{array}$ & $\begin{array}{l}5.348 \\
(8.12)\end{array}$ & $\begin{array}{l}1.902 \\
(2.66)\end{array}$ & $\begin{array}{l}1.957 \\
(3.64)\end{array}$ & $\begin{array}{l}4.307 \\
(6.80)\end{array}$ \\
\hline HusbNon-WageInc & $\begin{array}{l}2025.505 \\
(4271.17)\end{array}$ & $\begin{array}{l}1855.242 \\
(5086.61)\end{array}$ & $\begin{array}{l}1347.727 \\
(3456.13)\end{array}$ & $\begin{array}{l}1777.939 \\
(4912.63)\end{array}$ & $\begin{array}{l}2212.050 \\
(3898.42)\end{array}$ & $\begin{array}{c}1169.542 \\
(3195.05)\end{array}$ & $\begin{array}{c}414.627 \\
(1327.78)\end{array}$ & $\begin{array}{c}614.436 \\
(1920.66)\end{array}$ & $\begin{array}{l}0.597 \\
(2.53)\end{array}$ & $\begin{array}{l}3616.738 \\
(6378.44)\end{array}$ & $\begin{array}{l}1640.062 \\
(3351.43)\end{array}$ & $\begin{array}{c}432.686 \\
(2051.76)\end{array}$ & $\begin{array}{c}533.796 \\
(1657.48)\end{array}$ & $\begin{array}{c}860.891 \\
(2637.27)\end{array}$ \\
\hline WifeNon-WageInc & $\begin{array}{l}2400.428 \\
(4826.48)\end{array}$ & $\begin{array}{l}3406.671 \\
(5045.16)\end{array}$ & $\begin{array}{l}3907.233 \\
(4870.13)\end{array}$ & $\begin{array}{l}4483.919 \\
(7621.38)\end{array}$ & $\begin{array}{l}1563.077 \\
(3203.06)\end{array}$ & $\begin{array}{l}1680.182 \\
(2618.47)\end{array}$ & $\begin{array}{c}440.924 \\
(1426.85)\end{array}$ & $\begin{array}{c}869.619 \\
(1232.95)\end{array}$ & $\begin{array}{l}0.514 \\
(2.10)\end{array}$ & $\begin{array}{l}1944.135 \\
(4034.56)\end{array}$ & $\begin{array}{c}732.279 \\
(2068.92)\end{array}$ & $\begin{array}{c}342.062 \\
(1398.80)\end{array}$ & $\begin{array}{c}348.595 \\
(1247.23)\end{array}$ & $\begin{array}{c}1191.522 \\
(1943.32)\end{array}$ \\
\hline WifeParticipation & $\begin{array}{l}0.267 \\
(0.20)\end{array}$ & $\begin{array}{l}0.347 \\
(0.18)\end{array}$ & $\begin{array}{l}0.428 \\
(0.12)\end{array}$ & $\begin{array}{l}0.402 \\
(0.14)\end{array}$ & $\begin{array}{l}0.310 \\
(0.19)\end{array}$ & $\begin{array}{l}0.263 \\
(0.19)\end{array}$ & $\begin{array}{l}0.205 \\
(0.22)\end{array}$ & $\begin{array}{l}0.228 \\
(0.20)\end{array}$ & $\begin{array}{l}0.212 \\
(0.22)\end{array}$ & $\begin{array}{l}0.229 \\
(0.21)\end{array}$ & $\begin{array}{l}0.230 \\
(0.20)\end{array}$ & $\begin{array}{l}0.271 \\
(0.22)\end{array}$ & $\begin{array}{l}0.175 \\
(0.22)\end{array}$ & $\begin{array}{l}0.318 \\
(0.18)\end{array}$ \\
\hline Number of observations & 7615 & 8284 & 8356 & 6280 & 17623 & 5764 & 8814 & 5295 & 17344 & 1288 & 16442 & 13612 & 15524 & 8427 \\
\hline
\end{tabular}




\begin{tabular}{|c|c|c|c|c|c|c|c|c|c|c|c|c|c|c|}
\hline \multicolumn{15}{|l|}{ Wives } \\
\hline HusbPrimEduc & $\begin{array}{l}0.112 \\
(0.32)\end{array}$ & $\begin{array}{l}0.197 \\
(0.40)\end{array}$ & $\begin{array}{l}0.185 \\
(0.39)\end{array}$ & $\begin{array}{l}0.218 \\
(0.41)\end{array}$ & $\begin{array}{l}0.257 \\
(0.44)\end{array}$ & $\begin{array}{c}0.152 \\
(0.36)\end{array}$ & $\begin{array}{l}0.364 \\
(0.48)\end{array}$ & $\begin{array}{l}0.370 \\
(0.48)\end{array}$ & $\begin{array}{l}0.424 \\
(0.49)\end{array}$ & $\begin{array}{l}0.497 \\
(0.50)\end{array}$ & $\begin{array}{l}0.227 \\
(0.42)\end{array}$ & $\begin{array}{l}0.775 \\
(0.42)\end{array}$ & $\begin{array}{l}0.493 \\
(0.50)\end{array}$ & $\begin{array}{l}0.383 \\
(0.49)\end{array}$ \\
\hline \multirow{2}{*}{ HusbSeconEduc } & 0.786 & 0.321 & 0.426 & 0.432 & 0.447 & 0.502 & 0.245 & 0.395 & 0.410 & 0.245 & 0.507 & 0.125 & 0.196 & 0.228 \\
\hline & $(0.41)$ & $(0.47)$ & $(0.49)$ & $(0.50)$ & $(0.50)$ & $(0.50)$ & $(0.43)$ & $(0.49)$ & $(0.49)$ & $(0.43)$ & $(0.50)$ & $(0.33)$ & $(0.40)$ & $(0.42)$ \\
\hline \multirow{2}{*}{ HusbHighEduc } & 0.094 & 0.391 & 0.384 & 0.343 & 0.235 & 0.344 & 0.386 & 0.222 & 0.142 & 0.257 & 0.247 & 0.081 & 0.310 & 0.373 \\
\hline & $(0.29)$ & $(0.49)$ & $(0.49)$ & $(0.47)$ & $(0.42)$ & $(0.48)$ & $(0.49)$ & $(0.42)$ & $(0.35)$ & $(0.44)$ & $(0.43)$ & $(0.27)$ & $(0.46)$ & $(0.48)$ \\
\hline \multirow{2}{*}{ WifePrimEduc } & 0.223 & 0.168 & 0.197 & 0.191 & 0.272 & 0.278 & 0.398 & 0.296 & 0.348 & 0.539 & 0.275 & 0.719 & 0.449 & 0.434 \\
\hline & $(0.42)$ & $(0.37)$ & $(0.40)$ & $(0.39)$ & $(0.44)$ & $(0.45)$ & $(0.49)$ & $(0.46)$ & $(0.48)$ & $(0.50)$ & $(0.45)$ & $(0.45)$ & $(0.50)$ & $(0.50)$ \\
\hline \multirow{2}{*}{ WifeSeconEduc } & 0.653 & 0.286 & 0.394 & 0.356 & 0.384 & 0.557 & 0.232 & 0.461 & 0.494 & 0.284 & 0.502 & 0.130 & 0.199 & 0.235 \\
\hline & $(0.48)$ & $(0.45)$ & $(0.49)$ & $(0.48)$ & $(0.49)$ & $(0.50)$ & $(0.42)$ & $(0.50)$ & $(0.50)$ & $(0.45)$ & $(0.50)$ & $(0.34)$ & $(0.40)$ & $(0.42)$ \\
\hline \multirow{2}{*}{ WifeHighEduc } & 0.111 & 0.472 & 0.404 & 0.449 & 0.284 & 0.162 & 0.368 & 0.237 & 0.140 & 0.176 & 0.210 & 0.104 & 0.352 & 0.323 \\
\hline & $(0.31)$ & $(0.50)$ & $(0.49)$ & $(0.50)$ & $(0.45)$ & $(0.37)$ & $(0.48)$ & $(0.43)$ & $(0.35)$ & $(0.38)$ & $(0.41)$ & $(0.31)$ & $(0.48)$ & $(0.47)$ \\
\hline \multirow{2}{*}{ HusbAge } & 41.342 & 40.121 & 42.579 & 43.909 & 41.655 & 43.420 & 43.291 & 42.417 & 43.347 & 39.760 & 41.367 & 41.793 & 41.169 & 42.557 \\
\hline & $(10.42)$ & $(9.05)$ & (11.19) & (10.66) & $(10.32)$ & (10.59) & $(9.80)$ & (10.49) & $(9.80)$ & $(9.63)$ & $(9.86)$ & (11.47) & $(10.25)$ & (11.46) \\
\hline \multirow{2}{*}{ WifeAge } & 38.254 & 37.784 & 40.109 & 41.807 & 39.281 & 40.671 & 38.792 & 40.012 & 40.146 & 36.809 & 38.805 & 38.923 & 38.600 & 40.173 \\
\hline & $(9.58)$ & $(8.54)$ & (10.59) & $(10.03)$ & $(9.68)$ & $(9.96)$ & $(8.70)$ & $(9.73)$ & $(8.92)$ & $(8.55)$ & $(9.40)$ & $(10.73)$ & $(9.45)$ & (10.90) \\
\hline \multirow{2}{*}{ AgeDifference } & 3.070 & 2.344 & 2.453 & 2.091 & 2.369 & 2.750 & 4.634 & 2.421 & 3.210 & 2.944 & 2.557 & 2.835 & 2.596 & 2.383 \\
\hline & $(4.31)$ & $(4.07)$ & $(4.41)$ & $(4.01)$ & $(4.30)$ & $(4.16)$ & $(4.33)$ & $(3.92)$ & $(3.80)$ & (4.86) & (3.96) & (4.62) & (3.67) & $(4.77)$ \\
\hline \multirow{2}{*}{ Children $<12$} & 0.434 & 0.366 & 0.355 & 0.390 & 0.385 & 0.225 & 0.405 & 0.419 & 0.388 & 0.322 & 0.340 & 0.404 & 0.375 & 0.288 \\
\hline & $(0.50)$ & $(0.48)$ & $(0.48)$ & $(0.49)$ & $(0.49)$ & $(0.42)$ & $(0.49)$ & $(0.49)$ & $(0.49)$ & $(0.47)$ & $(0.47)$ & $(0.49)$ & $(0.48)$ & $(0.45)$ \\
\hline \multirow{2}{*}{ Children $<16$} & 0.858 & 1.101 & 0.911 & 0.968 & 0.926 & 0.727 & 1.023 & 1.318 & 0.844 & 1.004 & 0.873 & 0.896 & 0.857 & 0.798 \\
\hline & $(0.95)$ & $(1.05)$ & $(1.05)$ & $(1.12)$ & $(0.98)$ & $(0.91)$ & $(0.94)$ & $(1.23)$ & $(0.87)$ & $(1.01)$ & $(1.04)$ & $(0.92)$ & $(0.92)$ & $(1.01)$ \\
\hline \multirow{2}{*}{ HusbSelf-Employed } & 0.102 & 0.112 & 0.071 & 0.143 & 0.083 & 0.070 & 0.245 & 0.188 & 0.170 & 0.070 & 0.045 & 0.149 & 0.153 & 0.135 \\
\hline & $(0.30)$ & $(0.32)$ & $(0.26)$ & $(0.35)$ & $(0.28)$ & $(0.25)$ & $(0.43)$ & $(0.39)$ & $(0.38)$ & $(0.25)$ & $(0.21)$ & $(0.36)$ & $(0.36)$ & $(0.34)$ \\
\hline \multirow{2}{*}{ HusbWage-Earner } & 0.780 & 0.822 & 0.843 & 0.712 & 0.789 & 0.817 & 0.642 & 0.698 & 0.694 & 0.832 & 0.873 & 0.738 & 0.701 & 0.763 \\
\hline & $(0.41)$ & $(0.38)$ & $(0.36)$ & $(0.45)$ & $(0.41)$ & $(0.39)$ & $(0.48)$ & $(0.46)$ & $(0.46)$ & $(0.37)$ & $(0.33)$ & $(0.44)$ & $(0.46)$ & $(0.43)$ \\
\hline \multirow{2}{*}{ HusbWage } & 8.419 & 8.635 & 9.894 & 11.547 & 8.354 & 9.171 & 4.315 & 8.241 & 0.006 & 11.764 & 9.084 & 3.439 & 5.495 & 6.527 \\
\hline & $(6.12)$ & (5.26) & $(5.99)$ & $(9.46)$ & $(8.72)$ & (7.23) & (3.68) & (13.19) & $(0.00)$ & $(7.67)$ & $(7.40)$ & (3.63) & $(5.08)$ & $(5.81)$ \\
\hline \multirow{2}{*}{ WifeWage } & 7.048 & 7.963 & 9.234 & 10.295 & 7.706 & 6.552 & 4.302 & 7.218 & 0.007 & 10.903 & 8.080 & 3.328 & 5.313 & 5.922 \\
\hline & $(5.68)$ & $(4.03)$ & $(25.62)$ & $(9.32)$ & (6.88) & (6.34) & $(3.24)$ & $(7.09)$ & $(0.00)$ & $(8.07)$ & $(8.75)$ & $(2.88)$ & $(4.24)$ & $(7.86)$ \\
\hline \multirow{2}{*}{ HusbNon-WageInc } & 2517.009 & 2538.528 & 1761.033 & 3750.770 & 2807.368 & 1872.685 & 894.047 & 1032.872 & 1.495 & 4167.538 & 2211.000 & 922.560 & 1130.574 & 1272.431 \\
\hline & $(5039.66)$ & (14082.2) & (4306.20) & $(14882.8)$ & (5111.04) & $(4422.17)$ & $(2595.90)$ & $(2650.63)$ & $(4.36)$ & (7159.73) & $(4490.66)$ & $(3466.66)$ & $(2893.00)$ & (3336.48) \\
\hline \multirow{2}{*}{ WifeNon-WageInc } & 2329.866 & 2982.722 & 2898.999 & 3495.802 & 1015.532 & 1331.961 & 297.597 & 756.956 & 0.447 & 1772.625 & 513.332 & 203.070 & 335.230 & 985.124 \\
\hline & (4425.93) & $(4907.32)$ & (3941.09) & $(5560.03)$ & $(2370.71)$ & (2236.49) & (917.66) & (1087.38) & $(1.91)$ & (4493.73) & (1470.04) & (738.53) & (1187.87) & $(1746.65)$ \\
\hline \multirow{2}{*}{ WifeParticipation } & 0.397 & 0.441 & 0.455 & 0.460 & 0.409 & 0.353 & 0.441 & 0.388 & 0.452 & 0.385 & 0.325 & 0.433 & 0.416 & 0.388 \\
\hline & $(0.19)$ & $(0.16)$ & $(0.12)$ & $(0.15)$ & $(0.16)$ & $(0.19)$ & $(0.19)$ & $(0.20)$ & $(0.18)$ & $(0.20)$ & $(0.19)$ & $(0.19)$ & $(0.22)$ & $(0.18)$ \\
\hline Number of observations & 5523 & 6604 & 7790 & 6513 & 13589 & 4399 & 4884 & 3800 & 10403 & 774 & 12218 & 10271 & 7600 & 7839 \\
\hline
\end{tabular}


Table 3. Husband's and wife's income satisfaction

\begin{tabular}{|c|c|c|c|c|c|c|c|c|c|c|c|c|c|c|}
\hline & Austria & Belgium & Denmark & Finland & France & Germany & Greece & Ireland & Italy & Luxembourg & $\begin{array}{c}\text { The } \\
\text { Netherlands }\end{array}$ & Portugal & Spain & $\begin{array}{c}\text { United- } \\
\text { Kingdom } \\
\end{array}$ \\
\hline \multicolumn{15}{|l|}{ Husbands } \\
\hline HusbSeconEduc & & $\begin{array}{l}0.518 \\
(0.11)\end{array}$ & $\begin{array}{l}-0.426 \\
(-0.25)\end{array}$ & $\begin{array}{c}2.466^{* *} \\
(2.04)\end{array}$ & $\begin{array}{c}-2.604 * * \\
(-3.78)\end{array}$ & $\begin{array}{l}1.398 \\
(0.34)\end{array}$ & $\begin{array}{l}2.277 \\
(1.42)\end{array}$ & $\begin{array}{l}7.247^{*} \\
(1.75)\end{array}$ & $\begin{array}{l}0.705 \\
(0.70)\end{array}$ & $\begin{array}{l}4.551 \\
(1.09)\end{array}$ & $\begin{array}{c}-0.561^{* *} \\
(-2.74)\end{array}$ & $\begin{array}{l}1.128 \\
(0.47)\end{array}$ & $\begin{array}{l}6.602 \\
(1.42)\end{array}$ & $\begin{array}{l}-3.559^{*} \\
(-1.82)\end{array}$ \\
\hline HusbHighEduc & & $\begin{array}{l}2.244 \\
(1.26)\end{array}$ & $\begin{array}{l}1.819 \\
(1.31)\end{array}$ & $\begin{array}{c}4.774 * * \\
(3.45)\end{array}$ & $\begin{array}{l}0.464 \\
(0.80)\end{array}$ & $\begin{array}{c}9.578^{* *} \\
(2.66)\end{array}$ & $\begin{array}{c}3.541 * * \\
(2.18)\end{array}$ & $\begin{array}{l}3.280 \\
(1.36)\end{array}$ & $\begin{array}{c}2.341^{*} \\
(1.70)\end{array}$ & $\begin{array}{l}3.599 \\
(1.35)\end{array}$ & $\begin{array}{c}1.129^{* *} \\
(3.48)\end{array}$ & $\begin{array}{c}2.211 * * \\
(3.92)\end{array}$ & $\begin{array}{c}2.508 * * \\
(2.05)\end{array}$ & $\begin{array}{c}1.602 * * \\
(3.39)\end{array}$ \\
\hline WifeHighEduc & & $\begin{array}{l}-0.598 \\
(-1.50)\end{array}$ & $\begin{array}{l}-0.632 \\
(-0.89)\end{array}$ & $\begin{array}{c}-2.641 * * \\
(-2.17)\end{array}$ & $\begin{array}{c}1.816^{* *} \\
(3.83)\end{array}$ & $\begin{array}{c}-3.151^{* *} \\
(-2.02)\end{array}$ & $\begin{array}{l}-1.620 \\
(-1.15)\end{array}$ & $\begin{array}{l}-1.872 \\
(-0.72)\end{array}$ & $\begin{array}{l}-0.976 \\
(-0.56)\end{array}$ & $\begin{array}{l}-0.003 \\
(-0.00)\end{array}$ & $\begin{array}{l}0.261 \\
(0.90)\end{array}$ & $\begin{array}{l}-0.469 \\
(-0.22)\end{array}$ & $\begin{array}{l}-1.798 \\
(-1.10)\end{array}$ & $\begin{array}{l}0.068 \\
(0.17)\end{array}$ \\
\hline HusbAge & $\begin{array}{c}0.021^{* *} \\
(4.80)\end{array}$ & $\begin{array}{c}0.011^{* *} \\
(3.07)\end{array}$ & $\begin{array}{l}0.003 \\
(1.26)\end{array}$ & $\begin{array}{c}0.024 * * \\
(4.12)\end{array}$ & $\begin{array}{c}0.030 * * \\
(10.28)\end{array}$ & $\begin{array}{c}-0.043 * * \\
(-4.92)\end{array}$ & $\begin{array}{c}0.025^{* *} \\
(7.28)\end{array}$ & $\begin{array}{c}0.064^{* *} \\
(8.59)\end{array}$ & $\begin{array}{c}-0.010^{* *} \\
(-2.67)\end{array}$ & $\begin{array}{c}0.033^{* *} \\
(2.31)\end{array}$ & $\begin{array}{c}0.018^{* *} \\
(6.14)\end{array}$ & $\begin{array}{c}0.007 * * \\
(4.20)\end{array}$ & $\begin{array}{c}0.028^{* *} \\
(8.90)\end{array}$ & $\begin{array}{l}0.008 \\
(1.33)\end{array}$ \\
\hline AgeDifference & & $\begin{array}{l}-0.022 \\
(-0.76)\end{array}$ & $\begin{array}{l}-0.003 \\
(-0.23)\end{array}$ & $\begin{array}{l}0.009 \\
(0.58)\end{array}$ & $\begin{array}{c}-0.026^{* *} \\
(-2.72)\end{array}$ & $\begin{array}{l}-0.008 \\
(-0.29)\end{array}$ & $\begin{array}{l}-0.001 \\
(-0.05)\end{array}$ & $\begin{array}{l}-0.004 \\
(-0.10)\end{array}$ & $\begin{array}{l}0.004 \\
(0.37)\end{array}$ & $\begin{array}{l}-0.048 \\
(-1.23)\end{array}$ & $\begin{array}{l}-0.007 \\
(-1.50)\end{array}$ & $\begin{array}{l}0.004 \\
(0.53)\end{array}$ & $\begin{array}{l}0.013 \\
(0.67)\end{array}$ & $\begin{array}{l}-0.005 \\
(-0.72)\end{array}$ \\
\hline Children $<12$ & $\begin{array}{c}-0.103 * * \\
(-2.20)\end{array}$ & $\begin{array}{l}-0.017 \\
(-0.72)\end{array}$ & $\begin{array}{c}-0.057^{*} \\
(-1.90)\end{array}$ & $\begin{array}{l}-0.052 \\
(-0.93)\end{array}$ & $\begin{array}{c}-0.096^{* *} \\
(-4.30)\end{array}$ & $\begin{array}{l}-0.013 \\
(-0.37)\end{array}$ & $\begin{array}{l}0.010 \\
(0.31)\end{array}$ & $\begin{array}{l}-0.067 \\
(-1.54)\end{array}$ & $\begin{array}{l}-0.047 \\
(-1.35)\end{array}$ & $\begin{array}{l}-0.071 \\
(-1.28)\end{array}$ & $\begin{array}{c}-0.075 * * \\
(-3.45)\end{array}$ & $\begin{array}{l}-0.002 \\
(-0.11)\end{array}$ & $\begin{array}{c}0.060^{* *} \\
(2.25)\end{array}$ & $\begin{array}{l}0.019 \\
(0.55)\end{array}$ \\
\hline Children $<16$ & $\begin{array}{l}0.012 \\
(0.40)\end{array}$ & $\begin{array}{c}-0.050^{* *} \\
(-2.40)\end{array}$ & $\begin{array}{c}-0.120^{* *} \\
(-5.81)\end{array}$ & $\begin{array}{l}-0.018 \\
(-0.55)\end{array}$ & $\begin{array}{c}0.072 * * \\
(4.69)\end{array}$ & $\begin{array}{c}-0.135^{* *} \\
(-2.88)\end{array}$ & $\begin{array}{c}-0.071^{* *} \\
(-3.24)\end{array}$ & $\begin{array}{l}-0.035 \\
(-1.18)\end{array}$ & $\begin{array}{c}-0.066^{* *} \\
(-2.42)\end{array}$ & $\begin{array}{l}0.141 * \\
(1.79)\end{array}$ & $\begin{array}{l}-0.011 \\
(-0.74)\end{array}$ & $\begin{array}{l}-0.021 \\
(-1.41)\end{array}$ & $\begin{array}{c}-0.095 * * \\
(-4.76)\end{array}$ & $\begin{array}{c}-0.087 * * \\
(-2.49)\end{array}$ \\
\hline HusbWage & $\begin{array}{c}0.087^{* *} \\
(3.69)\end{array}$ & $\begin{array}{c}0.032^{* *} \\
(2.66)\end{array}$ & $\begin{array}{l}0.020 \\
(1.46)\end{array}$ & $\begin{array}{c}0.188^{* *} \\
(3.84)\end{array}$ & $\begin{array}{l}0.011^{*} \\
(1.90)\end{array}$ & $\begin{array}{c}0.055^{*} \\
(1.93)\end{array}$ & $\begin{array}{c}0.105 * * \\
(7.53)\end{array}$ & $\begin{array}{l}0.010 \\
(0.23)\end{array}$ & $\begin{array}{c}0.307 * * \\
(4.83)\end{array}$ & $\begin{array}{l}0.037 \\
(0.83)\end{array}$ & $\begin{array}{l}0.003 \\
(0.16)\end{array}$ & $\begin{array}{c}0.037^{* *} \\
(4.35)\end{array}$ & $\begin{array}{c}0.037 * * \\
(3.76)\end{array}$ & $\begin{array}{l}0.022 \\
(0.68)\end{array}$ \\
\hline WifeWage & $\begin{array}{l}0.014 \\
(1.32)\end{array}$ & $\begin{array}{c}0.019 * * \\
(2.73)\end{array}$ & $\begin{array}{c}0.033 * * \\
(3.84)\end{array}$ & $\begin{array}{l}-0.032 \\
(-0.98)\end{array}$ & $\begin{array}{c}0.016 * * \\
(2.63)\end{array}$ & $\begin{array}{l}-0.010 \\
(-0.54)\end{array}$ & $\begin{array}{c}0.030^{* *} \\
(4.45)\end{array}$ & $\begin{array}{l}0.018 \\
(0.49)\end{array}$ & $\begin{array}{c}0.099^{*} \\
(1.85)\end{array}$ & $\begin{array}{l}0.006 \\
(0.29)\end{array}$ & $\begin{array}{c}0.038^{* *} \\
(4.01)\end{array}$ & $\begin{array}{c}0.016^{* *} \\
(3.46)\end{array}$ & $\begin{array}{c}0.028^{* *} \\
(4.51)\end{array}$ & $\begin{array}{l}0.035 \\
(1.48)\end{array}$ \\
\hline HusbNon-WageInc & $\begin{array}{l}0.241 \\
(1.01)\end{array}$ & $\begin{array}{c}-0.166^{* *} \\
(-2.95)\end{array}$ & $\begin{array}{l}-0.577 \\
(-1.17)\end{array}$ & $\begin{array}{l}0.869 \\
(1.25)\end{array}$ & $\begin{array}{l}0.590 \\
(1.58)\end{array}$ & $\begin{array}{l}0.631 \\
(0.25)\end{array}$ & $\begin{array}{c}0.104 * * \\
(3.94)\end{array}$ & $\begin{array}{l}-6.686 \\
(-0.51)\end{array}$ & $\begin{array}{l}-0.949 \\
(-0.50)\end{array}$ & $\begin{array}{l}0.005 \\
(0.04)\end{array}$ & $\begin{array}{c}-4.158^{* *} \\
(-3.11)\end{array}$ & $\begin{array}{c}0.040 * * \\
(2.46)\end{array}$ & $\begin{array}{c}-0.086^{* *} \\
(-2.23)\end{array}$ & $\begin{array}{l}0.748 \\
(0.14)\end{array}$ \\
\hline WifeNon-WageInc & $\begin{array}{l}0.034 \\
(0.13)\end{array}$ & $\begin{array}{l}0.116^{*} \\
(1.90)\end{array}$ & $\begin{array}{c}0.902 * * \\
(2.36)\end{array}$ & $\begin{array}{l}-0.420 \\
(-0.88)\end{array}$ & $\begin{array}{c}-1.556^{* *} \\
(-3.49)\end{array}$ & $\begin{array}{l}0.612 \\
(0.17)\end{array}$ & $\begin{array}{l}0.039 \\
(1.28)\end{array}$ & $\begin{array}{r}-27.193 \\
(-1.39)\end{array}$ & $\begin{array}{l}2.385 \\
(0.68)\end{array}$ & $\begin{array}{l}-0.367^{*} \\
(-1.86)\end{array}$ & $\begin{array}{l}-0.459 \\
(-0.22)\end{array}$ & $\begin{array}{l}0.044 \\
(1.50)\end{array}$ & $\begin{array}{l}-0.008 \\
(-0.15)\end{array}$ & $\begin{array}{l}1.340 \\
(0.17)\end{array}$ \\
\hline WifeParticipation & $\begin{array}{l}-0.083 \\
(-0.56)\end{array}$ & $\begin{array}{c}-0.248^{* *} \\
(-2.09)\end{array}$ & $\begin{array}{l}-0.206 \\
(-1.55)\end{array}$ & $\begin{array}{c}0.908 * * \\
(2.88)\end{array}$ & $\begin{array}{l}0.085 \\
(1.07)\end{array}$ & $\begin{array}{l}0.173 \\
(1.06)\end{array}$ & $\begin{array}{l}-0.177 \\
(-1.62)\end{array}$ & $\begin{array}{c}0.387^{*} \\
(1.66)\end{array}$ & $\begin{array}{l}-0.221 \\
(-0.82)\end{array}$ & $\begin{array}{c}0.749^{* *} \\
(2.41)\end{array}$ & $\begin{array}{c}0.207 * * \\
(2.55)\end{array}$ & $\begin{array}{l}-0.073 \\
(-1.04)\end{array}$ & $\begin{array}{l}0.034 \\
(0.34)\end{array}$ & $\begin{array}{l}-0.294 * \\
(-1.84)\end{array}$ \\
\hline LM & $\begin{array}{l}3051.17 \\
(0.0000)\end{array}$ & $\begin{array}{l}5198.11 \\
(0.0000)\end{array}$ & $\begin{array}{l}2883.17 \\
(0.0000)\end{array}$ & $\begin{array}{l}1176.81 \\
(0.0000)\end{array}$ & $\begin{array}{l}8369.92 \\
(0.0000)\end{array}$ & $\begin{array}{l}902.67 \\
(0.0000)\end{array}$ & $\begin{array}{l}1307.60 \\
(0.0000)\end{array}$ & $\begin{array}{l}1277.06 \\
(0.0000)\end{array}$ & $\begin{array}{l}2132.94 \\
(0.0000)\end{array}$ & $\begin{array}{l}246.20 \\
(0.0000)\end{array}$ & $\begin{array}{l}6668.60 \\
(0.0000)\end{array}$ & $\begin{array}{l}5873.75 \\
(0.0000)\end{array}$ & $\begin{array}{l}3354.24 \\
(0.0000)\end{array}$ & $\begin{array}{l}1408.33 \\
(0.0000)\end{array}$ \\
\hline Hausman 1 & $\begin{array}{c}63.29 \\
(0.0000)\end{array}$ & $\begin{array}{c}41.32 \\
(0.0000)\end{array}$ & $\begin{array}{c}93.74 \\
(0.0000)\end{array}$ & $\begin{array}{c}70.50 \\
(0.0000)\end{array}$ & $\begin{array}{c}240.28 \\
(0.0000)\end{array}$ & $\begin{array}{c}193.94 \\
(0.0000)\end{array}$ & $\begin{array}{c}111.38 \\
(0.0000)\end{array}$ & $\begin{array}{c}135.69 \\
(0.0000)\end{array}$ & $\begin{array}{c}57.81 \\
(0.0000)\end{array}$ & $\begin{array}{c}45.46 \\
(0.0000)\end{array}$ & $\begin{array}{c}212.57 \\
(0.0000)\end{array}$ & $\begin{array}{c}137.24 \\
(0.0000)\end{array}$ & $\begin{array}{c}214.70 \\
(0.0000)\end{array}$ & $\begin{array}{c}125.96 \\
(0.0000)\end{array}$ \\
\hline Hausman 2 & $\begin{array}{c}0.54 \\
(0.0003)\end{array}$ & $\begin{array}{c}0.23 \\
(1.0000)\end{array}$ & $\begin{array}{c}6.20 \\
(0.6246)\end{array}$ & $\begin{array}{c}0.68 \\
(0.9996)\end{array}$ & $\begin{array}{c}2.30 \\
(0.9703)\end{array}$ & $\begin{array}{c}4.89 \\
(0.7688)\end{array}$ & $\begin{array}{c}0.18 \\
(1.0000)\end{array}$ & $\begin{array}{c}0.33 \\
(1.0000)\end{array}$ & $\begin{array}{c}1.72 \\
(0.9885)\end{array}$ & $\begin{array}{c}0.53 \\
(0.9998)\end{array}$ & $\begin{array}{c}2.90 \\
(0.9406)\end{array}$ & $\begin{array}{c}1.32 \\
(0.9953)\end{array}$ & $\begin{array}{c}0.18 \\
(1.0000)\end{array}$ & $\begin{array}{c}1.05 \\
(0.9979)\end{array}$ \\
\hline Selected estimation & $\mathrm{FE}$ & HT & HT & $\mathrm{HT}$ & $\mathrm{HT}$ & HT & HT & $\mathrm{HT}$ & $\mathrm{HT}$ & HT & HT & HT & $\mathrm{HT}$ & HT \\
\hline Number of observations & 7615 & 8284 & 8356 & 4615 & 17622 & 5764 & 8814 & 5295 & 7303 & 1288 & 16442 & 13612 & 15524 & 8427 \\
\hline
\end{tabular}




\begin{tabular}{|c|c|c|c|c|c|c|c|c|c|c|c|c|c|c|}
\hline \multicolumn{15}{|l|}{ Wives } \\
\hline WifeSeconEduc & $\begin{array}{l}-2.173 \\
(-1.08)\end{array}$ & $\begin{array}{l}1.398 \\
(1.09)\end{array}$ & $\begin{array}{l}-0.964 \\
(-1.57)\end{array}$ & $\begin{array}{l}1.744 \\
(2.18)\end{array}$ & $\begin{array}{l}-4.233 \\
(-0.80)\end{array}$ & $\begin{array}{c}-10.376^{* *} \\
(-2.78)\end{array}$ & $\begin{array}{l}1.517 \\
(1.09)\end{array}$ & $\begin{array}{l}0.734 \\
(0.94)\end{array}$ & $\begin{array}{c}0.780^{* *} \\
(2.10)\end{array}$ & $\begin{array}{l}-2.785 \\
(-1.37)\end{array}$ & $\begin{array}{c}-1.824 * * \\
(-2.57)\end{array}$ & $\begin{array}{l}-0.123 \\
(-0.20)\end{array}$ & $\begin{array}{c}4.594 * * \\
(3.18)\end{array}$ & $\begin{array}{l}1.429 \\
(1.27)\end{array}$ \\
\hline HusbHighEduc & $\begin{array}{l}5.188^{*} \\
(1.86)\end{array}$ & $\begin{array}{c}1.584 * * \\
(2.76)\end{array}$ & $\begin{array}{c}1.233 * * \\
(2.67)\end{array}$ & $\begin{array}{c}1.674 * * \\
(2.84)\end{array}$ & $\begin{array}{l}1.964 \\
(0.70)\end{array}$ & $\begin{array}{c}3.534 * \\
(1.74)\end{array}$ & $\begin{array}{l}-0.842 \\
(-0.46)\end{array}$ & $\begin{array}{l}0.125 \\
(0.25)\end{array}$ & $\begin{array}{l}0.734 \\
(0.91)\end{array}$ & $\begin{array}{l}1.049 \\
(0.39)\end{array}$ & $\begin{array}{c}2.201 * * \\
(2.00)\end{array}$ & $\begin{array}{l}1.094^{*} \\
(1.74)\end{array}$ & $\begin{array}{l}0.424 \\
(0.51)\end{array}$ & $\begin{array}{c}1.878^{* *} \\
(5.65)\end{array}$ \\
\hline WifeHighEduc & $\begin{array}{l}1.422 \\
(0.77)\end{array}$ & $\begin{array}{l}0.327 \\
(0.58)\end{array}$ & $\begin{array}{l}0.066 \\
(0.14)\end{array}$ & $\begin{array}{l}0.476 \\
(0.81)\end{array}$ & $\begin{array}{l}2.153 \\
(1.32)\end{array}$ & $\begin{array}{l}-2.697 \\
(-1.56)\end{array}$ & $\begin{array}{c}4.177^{* *} \\
(2.29)\end{array}$ & $\begin{array}{c}1.271 * * \\
(2.51)\end{array}$ & $\begin{array}{l}0.291 \\
(0.25)\end{array}$ & $\begin{array}{l}0.287 \\
(0.08)\end{array}$ & $\begin{array}{l}0.965 \\
(1.31)\end{array}$ & $\begin{array}{c}1.875^{* *} \\
(3.20)\end{array}$ & $\begin{array}{l}1.109 \\
(1.53)\end{array}$ & $\begin{array}{l}0.410 \\
(1.17)\end{array}$ \\
\hline WifeAge & $\begin{array}{l}0.001 \\
(0.12)\end{array}$ & $\begin{array}{c}0.014 * * \\
(3.01)\end{array}$ & $\begin{array}{c}0.010^{* *} \\
(3.16)\end{array}$ & $\begin{array}{c}0.028 * * \\
(5.17)\end{array}$ & $\begin{array}{c}0.028^{* *} \\
(8.89)\end{array}$ & $\begin{array}{c}-0.055^{* *} \\
(-3.22)\end{array}$ & $\begin{array}{c}0.026^{* *} \\
(4.15)\end{array}$ & $\begin{array}{c}0.028^{* *} \\
(4.04)\end{array}$ & $\begin{array}{l}-0.002 \\
(-0.38)\end{array}$ & $\begin{array}{l}-0.011 \\
(-0.56)\end{array}$ & $\begin{array}{c}0.022 * * \\
(6.94)\end{array}$ & $\begin{array}{l}-0.000 \\
(-0.01)\end{array}$ & $\begin{array}{c}0.043^{* *} \\
(7.76)\end{array}$ & $\begin{array}{c}0.024 * * \\
(4.56)\end{array}$ \\
\hline AgeDifference & $\begin{array}{l}0.010 \\
(0.50)\end{array}$ & $\begin{array}{l}-0.007 \\
(-0.70)\end{array}$ & $\begin{array}{l}0.011 \\
(1.30)\end{array}$ & $\begin{array}{l}0.020^{*} \\
(1.82)\end{array}$ & $\begin{array}{l}0.018 \\
(0.44)\end{array}$ & $\begin{array}{l}-0.064 * \\
(-1.85)\end{array}$ & $\begin{array}{l}0.032 * \\
(1.85)\end{array}$ & $\begin{array}{l}0.002 \\
(0.15)\end{array}$ & $\begin{array}{l}-0.002 \\
(-0.19)\end{array}$ & $\begin{array}{l}0.005 \\
(0.20)\end{array}$ & $\begin{array}{l}0.015 \\
(1.20)\end{array}$ & $\begin{array}{l}0.007 \\
(1.32)\end{array}$ & $\begin{array}{l}0.014 \\
(0.98)\end{array}$ & $\begin{array}{l}0.002 \\
(0.31)\end{array}$ \\
\hline Children $<12$ & $\begin{array}{c}-0.124 * * \\
(-2.16)\end{array}$ & $\begin{array}{l}-0.045 \\
(-1.57)\end{array}$ & $\begin{array}{c}-0.129 * * \\
(-3.85)\end{array}$ & $\begin{array}{l}-0.082 \\
(-1.54)\end{array}$ & $\begin{array}{c}-0.095^{* *} \\
(-3.95)\end{array}$ & $\begin{array}{l}-0.030 \\
(-0.54)\end{array}$ & $\begin{array}{c}0.087^{*} \\
(1.90)\end{array}$ & $\begin{array}{l}-0.065 \\
(-1.22)\end{array}$ & $\begin{array}{c}-0.058^{*} \\
(-1.65)\end{array}$ & $\begin{array}{l}-0.026 \\
(-0.28)\end{array}$ & $\begin{array}{c}-0.093 * * \\
(-3.68)\end{array}$ & $\begin{array}{l}0.017 \\
(0.68)\end{array}$ & $\begin{array}{l}-0.040 \\
(-0.96)\end{array}$ & $\begin{array}{c}-0.104 * * \\
(-3.04)\end{array}$ \\
\hline Children $<16$ & $\begin{array}{l}0.010 \\
(0.26)\end{array}$ & $\begin{array}{l}-0.011 \\
(-0.47)\end{array}$ & $\begin{array}{c}-0.089 * * \\
(-3.83)\end{array}$ & $\begin{array}{l}-0.015 \\
(-0.46)\end{array}$ & $\begin{array}{c}0.060^{* *} \\
(3.52)\end{array}$ & $\begin{array}{l}-0.098 \\
(-1.40)\end{array}$ & $\begin{array}{c}-0.090^{* *} \\
(-2.86)\end{array}$ & $\begin{array}{c}-0.088^{* *} \\
(-2.56)\end{array}$ & $\begin{array}{l}-0.000 \\
(-0.01)\end{array}$ & $\begin{array}{l}0.139 \\
(1.16)\end{array}$ & $\begin{array}{l}-0.017 \\
(-1.03)\end{array}$ & $\begin{array}{l}-0.032 \\
(-1.61)\end{array}$ & $\begin{array}{l}0.014 \\
(0.44)\end{array}$ & $\begin{array}{c}-0.105^{* *} \\
(-3.22)\end{array}$ \\
\hline HusbWage & $\begin{array}{c}0.051 * * \\
(3.39)\end{array}$ & $\begin{array}{l}0.016 \\
(1.45)\end{array}$ & $\begin{array}{c}0.056^{* *} \\
(4.85)\end{array}$ & $\begin{array}{l}0.028 \\
(0.65)\end{array}$ & $\begin{array}{c}0.014 * * \\
(2.36)\end{array}$ & $\begin{array}{c}0.069 * * \\
(2.29)\end{array}$ & $\begin{array}{c}0.020^{* *} \\
(1.97)\end{array}$ & $\begin{array}{c}0.268^{* *} \\
(5.92)\end{array}$ & $\begin{array}{c}0.262 * * \\
(4.99)\end{array}$ & $\begin{array}{c}0.078^{* *} \\
(2.02)\end{array}$ & $\begin{array}{c}0.101 * * \\
(7.32)\end{array}$ & $\begin{array}{c}0.036^{* *} \\
(6.12)\end{array}$ & $\begin{array}{c}0.054^{* *} \\
(6.18)\end{array}$ & $\begin{array}{c}0.168^{* *} \\
(7.31)\end{array}$ \\
\hline WifeWage & $\begin{array}{l}0.005 \\
(0.36)\end{array}$ & $\begin{array}{l}0.010 \\
(0.95)\end{array}$ & $\begin{array}{l}-0.001 \\
(-0.08)\end{array}$ & $\begin{array}{l}-0.004 \\
(-0.12)\end{array}$ & $\begin{array}{c}0.017 * * \\
(2.57)\end{array}$ & $\begin{array}{l}0.002 \\
(0.08)\end{array}$ & $\begin{array}{c}0.031 * * \\
(2.42)\end{array}$ & $\begin{array}{l}0.041 \\
(0.87)\end{array}$ & $\begin{array}{l}0.053 \\
(1.03)\end{array}$ & $\begin{array}{l}-0.059 \\
(-1.64)\end{array}$ & $\begin{array}{l}-0.006 \\
(-0.49)\end{array}$ & $\begin{array}{c}0.021^{* *} \\
(2.44)\end{array}$ & $\begin{array}{l}0.003 \\
(0.31)\end{array}$ & $\begin{array}{c}-0.097 * * \\
(-3.79)\end{array}$ \\
\hline HusbNon-WageInc & $\begin{array}{l}0.459 \\
(1.56)\end{array}$ & $\begin{array}{l}0.009 \\
(0.36)\end{array}$ & $\begin{array}{c}-1.300^{* *} \\
(-2.82)\end{array}$ & $\begin{array}{c}0.659^{*} \\
(1.89)\end{array}$ & $\begin{array}{c}0.660^{* *} \\
(2.11)\end{array}$ & $\begin{array}{l}-1.274 \\
(-0.43)\end{array}$ & $\begin{array}{c}0.075^{* *} \\
(3.04)\end{array}$ & $\begin{array}{l}6.870 \\
(0.60)\end{array}$ & $\begin{array}{c}3.473 * * \\
(1.98)\end{array}$ & $\begin{array}{l}-0.383^{*} \\
(-1.83)\end{array}$ & $\begin{array}{l}-0.770 \\
(-0.56)\end{array}$ & $\begin{array}{c}0.038 * * \\
(2.64)\end{array}$ & $\begin{array}{l}-0.008 \\
(-0.21)\end{array}$ & $\begin{array}{c}9.967 * * \\
(2.26)\end{array}$ \\
\hline WifeNon-WageInc & $\begin{array}{l}-0.492 \\
(-1.59)\end{array}$ & $\begin{array}{l}-0.073 \\
(-1.13)\end{array}$ & $\begin{array}{l}-0.798 \\
(-1.63)\end{array}$ & $\begin{array}{c}-2.529 * * \\
(-2.97)\end{array}$ & $\begin{array}{c}-1.085^{* *} \\
(-1.97)\end{array}$ & $\begin{array}{l}-3.990 \\
(-0.80)\end{array}$ & $\begin{array}{l}-0.057 \\
(-1.15)\end{array}$ & $\begin{array}{l}29.381 \\
(1.19)\end{array}$ & $\begin{array}{l}-0.914 \\
(-0.28)\end{array}$ & $\begin{array}{l}-0.021 \\
(-0.09)\end{array}$ & $\begin{array}{c}-15.854 * * \\
(-5.52)\end{array}$ & $\begin{array}{l}-0.014 \\
(-0.21)\end{array}$ & $\begin{array}{l}-0.011 \\
(-0.16)\end{array}$ & $\begin{array}{l}-2.975 \\
(-0.43)\end{array}$ \\
\hline WifeParticipation & $\begin{array}{l}0.062 \\
(0.42)\end{array}$ & $\begin{array}{l}-0.013 \\
(-0.10)\end{array}$ & $\begin{array}{l}0.088 \\
(0.61)\end{array}$ & $\begin{array}{l}-0.301 \\
(-1.13)\end{array}$ & $\begin{array}{l}-0.034 \\
(-0.42)\end{array}$ & $\begin{array}{l}0.238 \\
(1.18)\end{array}$ & $\begin{array}{l}0.008 \\
(0.05)\end{array}$ & $\begin{array}{l}0.215 \\
(0.89)\end{array}$ & $\begin{array}{c}0.786^{* *} \\
(3.20)\end{array}$ & $\begin{array}{l}0.536 \\
(1.22)\end{array}$ & $\begin{array}{c}0.102 \\
(1.24)\end{array}$ & $\begin{array}{c}0.219^{* *} \\
(2.75)\end{array}$ & $\begin{array}{l}0.125 \\
(1.01)\end{array}$ & $\begin{array}{c}0.456^{* *} \\
(3.60)\end{array}$ \\
\hline LM & $\begin{array}{l}1992.82 \\
(0.0000)\end{array}$ & $\begin{array}{l}3054.99 \\
(0.0000)\end{array}$ & $\begin{array}{l}2499.05 \\
(0.0000)\end{array}$ & $\begin{array}{l}1391.77 \\
(0.0000)\end{array}$ & $\begin{array}{l}5514.11 \\
(0.0000)\end{array}$ & $\begin{array}{c}603.45 \\
(0.0000)\end{array}$ & $\begin{array}{c}799.41 \\
(0.0000)\end{array}$ & $\begin{array}{c}944.91 \\
(0.0000)\end{array}$ & $\begin{array}{l}2461.96 \\
(0.0000)\end{array}$ & $\begin{array}{c}133.32 \\
(0.0000)\end{array}$ & $\begin{array}{l}4175.75 \\
(0.0000)\end{array}$ & $\begin{array}{l}4105.12 \\
(0.0000)\end{array}$ & $\begin{array}{l}1257.95 \\
(0.0000)\end{array}$ & $\begin{array}{c}994.30 \\
(0.0000)\end{array}$ \\
\hline Hausman 1 & $\begin{array}{c}57.56 \\
(0.0000)\end{array}$ & $\begin{array}{c}38.68 \\
(0.0000)\end{array}$ & $\begin{array}{l}100.95 \\
(0.0000)\end{array}$ & $\begin{array}{c}52.46 \\
(0.0000)\end{array}$ & $\begin{array}{c}148.29 \\
(0.0000)\end{array}$ & $\begin{array}{c}86.84 \\
(0.0000)\end{array}$ & $\begin{array}{c}132.36 \\
(0.0000)\end{array}$ & $\begin{array}{c}21.15 \\
(0.0068)\end{array}$ & $\begin{array}{c}71.86 \\
(0.0000)\end{array}$ & $\begin{array}{c}15.99 \\
(0.0425)\end{array}$ & $\begin{array}{c}94.71 \\
(0.0000)\end{array}$ & $\begin{array}{c}91.59 \\
(0.0000)\end{array}$ & $\begin{array}{c}127.35 \\
(0.0000)\end{array}$ & $\begin{array}{c}121.99 \\
(0.0000)\end{array}$ \\
\hline Hausman 2 & $\begin{array}{c}0.82 \\
(0.9991)\end{array}$ & $\begin{array}{c}2.01 \\
(0.9806)\end{array}$ & $\begin{array}{c}9.08 \\
(0.3353)\end{array}$ & $\begin{array}{c}2.16 \\
(0.9756)\end{array}$ & $\begin{array}{c}0.00 \\
(1.0000)\end{array}$ & $\begin{array}{c}0.08 \\
(1.0000)\end{array}$ & $\begin{array}{c}1.23 \\
(0.9963)\end{array}$ & $\begin{array}{c}4.72 \\
(0.7876)\end{array}$ & $\begin{array}{c}2.07 \\
(0.9787)\end{array}$ & $\begin{array}{c}0.07 \\
(1.0000)\end{array}$ & $\begin{array}{c}0.31 \\
(1.0000)\end{array}$ & $\begin{array}{c}0.03 \\
(1.0000)\end{array}$ & $\begin{array}{c}0.45 \\
(0.9999)\end{array}$ & $\begin{array}{c}0.17 \\
(1.0000)\end{array}$ \\
\hline Selected estimation & HT & HT & HT & HT & HT & HT & HT & HT & HT & HT & HT & HT & HT & HT \\
\hline Number of observations & 5523 & 6604 & 7790 & 5187 & 13589 & 4399 & 4884 & 3800 & 8317 & 774 & 12218 & 10271 & 7600 & 7839 \\
\hline
\end{tabular}

